\title{
The Paradox of Agency Responsiveness: A Federal FOIA Experiment*
}

\begin{abstract}
For governments to be democratic they must carry out the will of citizens, either indirectly through elected officials or directly. Political science research on agency responsiveness has focused primarily on agency responsiveness to political principals, with an underlying assumption that responsiveness to political principals equates with responsiveness to citizens. Recently, there has been growing attention by policymakers to direct agency responsiveness to the people through open government laws and regulations. There are good reasons to believe that there is a tradeoff between accountability to elected officials and accountability to the public directly. In this paper we explain how designing agencies to be responsive to political principals can undermine their ability to be responsive directly to the people. We provide evidence for our claim using responsiveness to federal Freedom of Information Act (FOIA) requests as a case study. We use a repeated measures experiment involving citizen FOIA requests to 132 federal agencies. We find that the agencies designed to be the most responsive to elected officials are the least responsive to citizen FOIA requests. There is no evidence that they are more likely to otherwise respond adversely to the requester (claim more exemptions, charge fees, misunderstand request, harass requester). Our results have important implications for the way we conceptualize democratic accountability, the way judges decide about whether to defer to agency judgments, and our understanding of agency performance more generally.
\end{abstract}

Word Count: 9012

\author{
David E. Lewis \\ Vanderbilt University
}

Abby K. Wood

U.C. Berkeley

\footnotetext{
* A previous version of this paper was presented at the 2012 annual meeting of the Midwest Political Science Association, April 12-15, Chicago, IL. We thank Joshua Clinton for the original idea to use FOIA responses as data and Evan Haglund, John Hudak, Gbemende Johnson, Saskia Lewis, and Jennifer Selin for excellent research assistance. We thank Justin Fox, George Krause, David Nixon, Rajdeep Pakanati, Charis Wilson and seminar audiences at the London School of Economics, U.C. Berkeley, the University of Exeter, and Yale University for generous and helpful feedback. We thank Benjamin Goldblatt and Tegan Milspaw for their cooperation with this project. The errors that remain are our own.
} 
Responsiveness defines democratic governance. For governments to be democratic they must carry out the will of citizens, either indirectly through elected officials or directly in response to citizen requests. A significant amount of work in political science and law examines why some administrative agencies are responsive or democratically accountable and some are not and why this might vary over time. In this research, agency responsiveness has generally been conceived of as responsiveness to political principals, to the executive and (to a lesser extent) to the legislature. The courts have also adopted the assumption that responsiveness to political principals helps to enable democratic accountability of agencies, using agencies' greater democratic accountability as a reason for judicial deference to agency decisions (Chevron U.S.A Inc. v. National Resources Defense Council). ${ }^{1}$

Central to this research and jurisprudence are questions of agency design. From the moment they are created, agencies have different levels of political insulation that determine their level of responsiveness to elected officials (see, e.g., Lewis 2003; Moe 1989; Seidman 1998; Wood and Bohte 2004). Independent regulatory commissions like the Federal Trade Commission or Nuclear Regulatory Commission, for example, are designed to be insulated from political control. Other agencies, such as cabinet departments, are not designed with insulation from public pressures as a primary goal. These agencies are therefore much less insulated from elected politicians and arguably more democratically accountable.

In recent years, policymakers have become increasingly interested in another kind of agency responsiveness - responsiveness directly to the people through the various open government laws. The White House Open Government Initiative has a specific focus on

\footnotetext{
${ }^{1} 467$ U.S. 837 (1984).
} 
information availability directly to the public. ${ }^{2}$ From creating centralized government websites such as data.gov and foia.gov to ease citizen information searches to de-classifying documents and ramping up Freedom of Information Act responsiveness, the Obama Administration reports that it has made progress in opening up government and encouraging agencies to be more directly responsive to citizens. Congress has also allocated substantial time and attention to increasing public access to information. For example, one of Rep. Darrell Issa's (R-CA) first priorities after taking over the chairmanship of the House Committee on Oversight and Government Reform was overseeing agencies' responsiveness to Freedom of Information Act Requests. ${ }^{3}$ Senators Charles Grassley (R-IA) and Patrick Leahy (D-VT) similarly have publicly sought changes in the Department of Justice's rules on FOIA requests. ${ }^{4}$

There are at least three possible reasons why responsiveness to political principals does not equate with responsiveness to the public. First, more "political" agencies can be less responsive because electoral or political motivations may be inconsistent with the demands of public accountability. For example, agencies acting at the behest of elected officials may want to keep certain information hidden if this information is potentially embarrassing for elected officials. Added layers of political review can reduce openness by preventing the release of embarrassing information and generating delay on eventually-released information. Second, agencies designed to be responsive to elected officials can be less responsive to the public

\footnotetext{
${ }^{2}$ See Hansell, Saul. 2009. "Ideas Online, Yes, but Some Not So Presidential." New York Times, June 22, 2009 (http://www.nytimes.com/2009/06/23/technology/internet/23records.html, last accessed March 16, 2012) and the White House's own description of the project (www.whitehouse.gov/open, last accessed March 16, 2012).

${ }^{3}$ Lipton, Eric. 2011. "Republican Congressman Proposes Tracking Freedom of Information Act Requests." New York Times, January 28, 2011 (http://www.nytimes.com/2011/01/29/us/politics/29issa.html, last accessed March 8, 2012). See also O'Keefe, Ed. 2012. "Agencies Poorly Tracking FOIA Requests, Report Says.” Washington Post, March 15, 2012 (http://www.washingtonpost.com/blogs/federal-eye/post/agencies-poorly-track-foia-requests-reportsays/2012/03/14/gIQANneaCS_blog.html, last accessed March 16, 2012).

${ }^{4}$ Gerstein, Josh. 2012. "Patrick Leahy, Chuck Grassley on Warpath Over Stalled FOIA Recommendations." Politico, March 13, 2012 (http://www.politico.com/blogs/under-the-radar/2012/03/patrick-leahy-chuck-grassley-onwarpath-over-stalled-117303.html, last accessed March 16, 2012).
} 
because agency efforts to respond to the demands of elected officials can take valuable time and resources away from other agency activities, which include responding to the public. Finally, agencies designed to be responsive to political principals may experience generic management difficulties that affect performance in multiple areas, including citizen requests for information.

In this paper we address the question of whether there is a tradeoff between designing agencies to be responsive to elected officials and designing them to be responsive to citizens by looking at the case of agency responsiveness to Freedom of Information Act (FOIA) requests. Under FOIA individual citizens may request any record and the agency is obligated to reply with the record within 20 working days. ${ }^{5}$ We submitted a two FOIA requests to federal agencies. ${ }^{6}$ The requests were identical, varying only by how politically sensitive they were. Since the entire federal executive branch is subject to the same FOIA requirements, we create a measure of responsiveness by recording features of agency responses such as response times, the number of exemptions claimed, and whether fees were erroneously charged. We find that the agencies designed to be the most responsive to elected officials are the least likely to respond to our requests and the slowest when they do respond. We further find that the delay in responding carries over to an identical request sent by Rep. Issa shortly before our requests were sent. Politicized agencies were slower to respond not only to us, but also to a political principal, which leads us to believe that the mechanism of delay is not about hiding information from the public, but rather crowding out of low priority activities like FOIA or generic management challenges. We find no evidence that more politicized agencies are more likely to otherwise respond adversely to the requester (charge fees, misunderstand request, or harass the requester). Our

\footnotetext{
${ }^{5}$ We provide more details about the FOIA process below.

${ }^{6}$ The data requested through the Freedom of Information Act is information relevant to other research projects at the authors' universities but requested in such a way that the process of responding to these requests also provides useful information in its own right.
} 
findings have important implications for theories about democratic governance, the way courts should make decisions about whether to defer to agency judgments, and federal agency performance more generally.

\section{AGENCIES AND RESPONSIVENESS}

Scholars of political science and law have theorized about the responsiveness of government agencies. From the moment they are created, agencies have different levels of political insulation that determine their level of responsiveness to elected officials (see, e.g., Lewis 2003; Moe 1989; Seidman 1998; Wood and Bohte 2004). Responsiveness to the president has been emphasized by legal scholars who argue for a unitary executive (Calabresi 1995) and those who champion the power of the president and executive branch in policymaking (Kagan 2001; Lessig and Sunstein 1994; Pierce 1989), as well as by political scientists explaining what causes variation in political accountability (see, e.g., Lewis 2008; Moe 1985, 1989; Wood and Waterman 1994). The president has a variety of administrative tools including influence over the selection and retention of personnel, presidential directives (e.g., executive orders, national security directives), spending flexibility, regulatory review, control over federal litigation, and day-to-day decisions about how to prioritize the energies and resources of the federal government in the administration of law (Devins and Herz 1998; Fisher 2000; Howell 2003; Mayer 2001; Nathan 1975; Waterman 1989). Ultimately, the president is accountable to the people, and the logic of that accountability is that if the people disapprove of agency performance, they can change the party in control of the agencies by changing the chief executive - every four years, the people have the ability to exercise this sort of indirect accountability. 
Agencies are also responsive to political principals in the legislature, who create and oversee most agencies (see e.g., Aberbach 1990; Dodd and Schott 1979; McCubbins and Schwartz 1984; Weingast and Moran 1983). Legislative committees, responding to public opinion, can hold agencies accountable by conducting oversight hearings that communicate public disapproval of agency activities. The legislature controls the power of the purse and thereby appropriations (Article I), which allows it to reduce agency funding in response to public dissatisfaction with agency performance. The legislature can also threaten to grant or withhold authorization or appropriations and otherwise creatively sanction executive officials with a variety of tactics ranging from public sanction to the elimination of agencies or programs valued by executives. This provides the legislature tremendous leverage to influence the behavior of agency appointees, another avenue for political accountability of agencies.

But are agencies really accountable to the people via the president and Congress? Certainly, some are more accountable than others. Independent central banks like the Federal Reserve, for example, are designed to be insulated from political control so that the government can resist public pressures to manipulate monetary policy (e.g., inflate the currency to ease the payment of debts). Other agencies, like cabinet departments, are not designed with insulation from public pressures as a primary goal. These agencies are headed by political appointees who are removable at will by the president.

Agencies' democratic accountability is offered as a rationale to justify judicial deference to agency decisions. In Chevron v. NRDC, the Supreme Court rationalized its prescription of broad deference to agencies by noting that judges are not part of a political branch, but agencies, which "are not directly accountable to the people," are accountable through the President. ${ }^{7}$ This

\footnotetext{
${ }^{7}$ Chevron at $865-866$.
} 
is a rationale that has persisted over time. ${ }^{8}$ In the sense of accountability enabling the people to directly remove an official from office, it is true that agencies are not directly accountable. However, people make direct claims on agencies all the time, from FOIA requests to proposing regulations and participating in the notice and comment process. In that sense, agencies can indeed be directly responsive to the people. That responsiveness is the key component of accountability, and when that responsiveness is lacking, democratic accountability decreases.

\section{Agencies and Direct Responsiveness}

There are a number of reasons why designing agencies to be responsive to political direction can decrease responsiveness to the public. The relationship between citizens and government agencies is a series of principal-agent relationships, first between citizens and their elected officials, second between elected officials and agency appointees, and then between appointees and the government agencies they manage. Generic sources of agency loss in principal-agent relationships stem from the inability of principals to write specific contracts outlining a schedule of rewards and punishments for the delivery of specific outputs. Divergent preferences between principals and agents and information asymmetries between these actors induce agents to take actions that deviate from those preferred by the principal. There can be agency loss in each portion of this delegation chain, leading to substantial divergence between what citizens want and agencies produce. Intuitively, one might think that removing links in the chain by making public interaction with agencies direct would reduce agency losses. Direct citizen involvement with agencies unmediated creates agency losses of its own, however.

\footnotetext{
${ }^{8}$ In addition to the lack of direct accountability, members of the court have recognized variations in accountability based on the degree of independence from political pressures. See, e.g., FCC v. Fox and Humphrey's Executor, supra, n. 7, and Freytag, v. Commissioner of Internal Revenue, 501 U.S. 868, 907, 916 (1991), Scalia, dissenting).
} 
To begin, it is difficult for agencies to determine how to be responsive to the public since the public is comprised of millions of persons who disagree about what agencies should be doing. Elected officials are better positioned by democratic legitimacy and skill to interpret the meaning of elections and translate electoral outcomes into directions for administrative agencies, particularly since elected officials also have significantly more information about agency activities than citizens do. Citizen requests for agency activity - such as the provision of government information - may not reflect the preferences of a majority of citizens. While an overwhelming majority of citizens may agree with the goal of agency transparency and responsiveness to citizens, they disagree about how much emphasis to place on citizen requests relative to other agency tasks. Citizens also disagree about which citizen requests have merit and if, how, and when agencies should respond to such requests.

Not only is it difficult for persons to communicate majority interests to agencies effectively, citizen instruments of sanction are blunt and not very credible. Citizens that are unhappy with agency activity cannot threaten to withhold appropriations, hold hearings, or attach riders to appropriations bills. They can only complain and ask their elected representatives to do these things or, in rare circumstances, they may bring suit against the agency in federal court. When persons go directly to agencies to change policy, they lack the ability to credibly reflect a majority opinion and the tools to reward or sanction agencies. Agencies, therefore, are naturally more responsive to elected officials, whose views are easier to divine and whose ability to sanction is significantly more credible.

Understandably, agency responsiveness to elected officials and their appointees is usually good news for democratic accountability. Citizens can elect officials who direct agencies according to majority preferences. Elected officials can synthesize public opinion and use their 
superior information and tools of sanction to direct agencies to produce the right types of policy outputs.

Problems emerge, however, when elected officials and the public have significantly different views about agency activities. In the case of citizen requests for information, for example, the president and his appointees may prefer to keep certain information hidden from the public if this information is potentially embarrassing for the administration. This can make more "political" agencies less responsive to citizen requests for information than other agencies. Agencies will refuse more requests for information and be less forthcoming in the information they do produce. Concern about the release of politically embarrassing information leads appointees to introduce additional layers of political review. ${ }^{9}$ This generates delay and more conservative decisions on the release of information.

The relationship between principals and agents is also complicated in this context by the fact that voters ask elected officials to deal with multiple different issues. Given constraints in time, attention, and resources, agencies cannot prioritize all agency activities at the same time. The stronger the tie between the agency and elected officials - e.g., through an increase in the number of appointees - the more effort and resources the agency will allocate toward being responsive to elected officials. This kind of responsiveness is likely to direct resources to policyrelated work like rulemaking, and away from less policy-related work, like filling FOIA requests. Usually, the effect of this will be to crowd out effort and attention allocated to being responsive directly to citizens. Interestingly, in the rare cases where FOIA requests come from elected officials themselves, the lack of energy and attention that the agency gives to FOIA as a general

\footnotetext{
${ }^{9}$ This is consistent with emails obtained by the Associated Press indicating that one reason for the delay in response to some FOIA requests was screening by political appointees. Wald, Matthew L. 2012. "Slow Responses Cloud Window Into Washington." New York Times, January 28, 2012 (http://www.nytimes.com/2012/01/29/us/slowfreedom-of-information-responses-cloud-a-window-into-washington.html?pagewanted=all, last accessed May 23, 2012).
} 
matter, because it is so busy responding to elected officials' policy concerns, can work to reduce FOIA responsiveness to elected officials' FOIA requests. In other words, the energy and resources that agencies direct toward responding to elected officials is not tied to the officials themselves, but to the kinds of tasks that elected officials usually care about - meaning that in more politicized agencies, non-policy-related tasks, like FOIA, will take a backseat to policyrelated tasks. And once that infrastructure has developed, even elected officials will see less responsiveness to their FOIA requests in highly politicized agencies.

Finally, aggressive micromanagement by principals that comes in more "political" agencies can reduce incentives for agents to spend time and effort developing expertise, processes, and procedures that will benefit the agency and the public more generally (see, e.g., Gailmard and Patty 2007; Lewis 2008; Stephenson 2011). When appointees cannot credibly commit to not intervening in agency decision-making, agency performance can suffer across the board, not only in the FOIA process but in other areas as well. Employees are reluctant to go the extra mile to improve processes like FOIA since doing so may not be rewarded. Appointees are reluctant to reward civil service employees with the top jobs in agencies by replacing other appointees, and agency managers are restricted in their ability to reward civil servants with higher pay or benefits by federal pay guidelines. This makes it hard for the agency to recruit and retain the most expert career employees. While some agencies are structurally designed to limit political influence, others allow significant political influence. These differences across agencies have systematic effects on agency competence (Gallo and Lewis 2012; Gilmour and Lewis 2006; Heclo 1977; Lewis 2008).

In total, agencies designed to be most responsive to political principals may not be directly democratically accountable to the people. Most social science literature to date on this 
topic has lumped the two kinds of responsiveness into an umbrella of "democratic accountability", but we argue here that they are distinct, and indeed that the institutional design of agencies creates a tradeoff between responsiveness to political or democratic principals. Divergent preferences between appointees and citizens, the crowding out that comes from responsiveness to elected officials, and generic management problems stemming from too much political intervention suggest a tradeoff between accountability to political officials and the public.

\section{DATA AND ANALYTIC STRATEGY}

To evaluate the responsiveness of agencies to citizens we examine citizen requests for information. We employ a within subjects experiment involving identical control and treatment Freedom of Information Act requests to 132 agencies. We analyze data about confirmation and response times and the quality of responses. We conclude the data analysis by comparing responses to our requests with responses to similar requests by the Chair of the House Government Oversight and Reform Committee, Darrell Issa, months before our request.

\section{Freedom of Information Act Requests}

Evaluating the relationship between structural features-like the number of political appointments - and responsiveness is difficult because few comparable measures of agency responsiveness (or performance more generally) exist. An examination of the timing and quality of responses to identical FOIA requests provides a unique measure of agencies' direct democratic accountability. ${ }^{10}$ Under the Freedom of Information Act (1966) any person can

\footnotetext{
${ }^{10}$ The measure in the time domain is particularly interesting, as most inter-agency comparisons focus on policyrelated outputs, which are hard to generalize across the entire bureaucracy (for the outputs frequently used, see
} 
request any agency record not covered by one of 9 exemptions. ${ }^{11}$ Once the agency receives a request, the FOIA requires that it confirm receipt within 10 business days and issue a determination within 20 business days of receiving a request, excluding weekends and holidays. ${ }^{12}$ This determination can be to fill the request, fill it in part, decline the request, or indicate that the agency has no records responsive to the request. Agencies may ask for extensions to this time frame or stop working on a request until the requester provides fees or clarifying information. After the agency responds to the request, if the requestor disagrees with any exemptions or non-response, she may file an appeal within the agency. If she remains unsatisfied after appeals within the executive branch, the requestor's next remedy is in the courts.

On May 9, 2011, we submitted FOIA requests to almost all agencies in the federal government. ${ }^{13}$ These totaled 264 requests targeting only the FOIA office (132 of each type). Our requests, sent by different people on the same day, are located in Appendix B. Each agency received a baseline (control) and sensitive (treatment) request and we measure the time it took for the agency to confirm our request and respond to our request if they responded. We also note the number of exemptions claimed and the quality of the response for each request. The baseline request asks agencies to provide "the agency's FOIA log from 2010 or equivalent listing the

generally Van Thiel and Leeuw, 2002). Here we analyze a managerial task, rather than a political one, and we are able to time to complete identical tasks across agencies.

${ }^{11}$ These exemptions are: (b)(1) EXEMPTION - Protects Classified Matters of National Defense or Foreign Policy; (b)(2) EXEMPTION - Internal Personnel Rules and Practices; (b)(3) EXEMPTION - Information Specifically Exempted by Other Statutes; (b)(4) EXEMPTION - Trade Secrets, Commercial or Financial Information; (b)(5) EXEMPTION - Privileged Interagency or Intra-Agency Memoranda or Letters; (b)(6) EXEMPTION - Personal Information Affecting an Individual's Privacy; (b)(7) EXEMPTION - Investigatory Records Compiled for Law Enforcement Purposes; (b)(8) EXEMPTION - Records of Financial Institutions; (b)(9) EXEMPTION Geographical and Geophysical Information Concerning Wells. This list provided by the Department of Commerce (http://www.osec.doc.gov/omo/foia/exemptions.htm, last accessed June 12, 2011).

${ }^{12}$ In order to make a FOIA request, one must only send a request to the agency stating the records requested, willingness to pay for searching time and photocopies, the fee category of the request, and contact information.

13 If two agencies shared a FOIA office or officer, we only sent the request to the "parent" agency that hosted the FOIA office. This design choice resulted in our excluding all military commands (like Africa Command and Northern Command) and a few other DoD sub-agencies, as well as a few other agencies in similar situations. For the complete list of cases and those we excluded, see Appendix A. 
FOIA request number, name of requester, and a description of the records being requested." The politically sensitive request asks for "A list of FOIA requests from 2010 about which a political appointee (persons appointed under Schedule C, a non-career member of the Senior Executive Service, or a Senate-confirmed appointee) personally made an inquiry, personally reviewed, or personally had a hand in the disposition of the request." ${ }^{14}$ Each request was mailed with a return address of a private citizen but the letter notes that the request for information is for educational purposes. We analyze these measures of responsiveness to determine whether agencies designed to be responsive to elected officials are less responsive to our FOIA requests than other agencies and particularly less responsive to politically sensitive requests.

\section{Threats to Validity}

Of the commonly-discussed threats to experimental validity, our project is most susceptible to testing effects and SUTVA violations. ${ }^{15}$ In designing the experiment, we faced tradeoffs. One was whether we should send both requests from Location A (Author 1's location), or randomize whether the requests came from Location A or Location B (Author 2's location). Because of the different political reputations of the two cities, we chose to send all requests from Location A. That left us vulnerable to testing threats to validity, because both baseline and sensitive requests came from the same place, which could have sensitized the respondents into changing their behavior in response to the two "treatments". The FOIA logs

\footnotetext{
${ }^{14}$ One possible complication is that agencies with large backlogs may perceive the request for a log of FOIA requests as more politically sensitive than a request for all of the FOIA requests reviewed by appointees. We do not think this is a problem because FOIA logs are requested regularly. In addition, of our baseline request is perceived as more sensitive this should diminish the difference between the baseline and sensitive request, mitigating against our finding differences. We have also estimated models controlling for the number of backlogged requests and the results are similar to what is reported in Table 3.

${ }^{15}$ The education literature refers to a similar threat: diffusion of treatment. We refer here to the Rubin causal framework's concept of SUTVA, which encompasses diffusion of treatment and is more common in political science literature (Rubin 1974).
} 
that we received in response to our baseline treatment condition indicated FOIA requests are often made not only from the same city, but they seem to be made in batches, from the same person. An interview with a former FOIA officer confirmed that it is considered good practice to separate out each request, such that seeing multiple requests from the same person does not surprise FOIA offices. The testing threat to validity is therefore weak to non-existent. Moreover, to the extent that the "subject" agency officials are responding more quickly or more thoroughly to the sensitive request as a result of having exposure to the (simultaneous) baselines request, the validity threat would work against our finding differences.

The SUTVA (stable unit treatment value) assumption is that there is no interference between treatments (Rubin 1974), and that there are not different versions of treatment varying in effectiveness (Rubin 1990). One possible violation of SUTVA in our research design, which manifests as a multiple treatment effect, is that a woman sent our baseline requests, and a man sent our sensitive requests. If this resulted in a multiple treatment effect, it could be understood in the baseline case as the treatment being the baseline request sent by a woman, where the potential outcome that we observe is a response to that treatment, but unobserved potential outcomes now include the baseline request sent by a man, and then comparing baseline-woman to sensitive-man expands the number of potential outcomes, adding baseline-man and sensitivewoman to the list. There are two reasons that this aspect of our design does not threaten our inference. First, all agencies received letters from the same senders. The woman sent all of the baseline requests, and the man sent all of the sensitive requests, to all agencies. Our results are therefore not biased, and internal validity is not threatened. Secondly, under standard concepts of sexism, we would expect that the man would receive faster responses than the woman. This would work against our finding a difference between the baseline and sensitive requests. If 
sexism is at work, it causes us to underestimate the magnitude of our findings - in other words, this violation works against us.

We did have one interesting brush with validity, and it was one we could not have anticipated. The General Counsel of the Postal Regulatory Commission also runs a FOIAcentered website called governmentattic.org, which regularly requests FOIA logs from various agencies. He called one of the senders in Nashville to tell him that he knew the sender had sent an identical request to all agencies in the government. The General Counsel/website affiliate did not know this from his work as an agency official; rather he must have known it from his work for the website. This is a violation we could not have anticipated. Our results are robust to removing the Postal Regulatory Commission data from the dataset.

\section{FOIA Responses by Agency Type}

The normal procedure for agencies is to send a confirmation by letter or email that they have received a request and they assign the request a unique case identifier. In some cases the confirmation and determination arrive in the same communication (i.e., we received your request and here is the determination). The first agency confirmations and determinations arrived on May 12, 2011. For the analysis in this paper the last data collected in response to these requests was received May 9, 2012, one year from the date we sent the letters, which is comfortably longer than 20 working days from the time a request would reasonably be expected to reach an agency FOIA office. Out of 264 requests, we received confirmation of 219 by May 9, 2012 $(83 \%)$. The average time to confirmation, if we give all of the outstanding requests the maximum time observed to date, is 79 days. Out of 264 agencies, 195 filled the request by May 9 (74\%), and the average time was 122 days, giving non-responses the maximum time observed to date. 
Table 1 provides the list of agencies that had not filled either the baseline or treatment request sent to them after 365 days.

\section{[Insert Table 1 Here]}

Filling the request does not mean that agencies gave us the information we were seeking. Rather, this implies that they made a determination about the release of records. For agencies that made a determination, we collected data on the number of exemptions claimed and the quality of the response. Among the 195 cases in which an agency provided us some form of response, 125 sent us records and 70 responses indicated the agency had no records responsive to our request. Of the 125 sets of records sent by agencies, $42(32 \%)$ included material redacted due to exemptions. Of the 195 responses, 40 (20.51\%) agencies had responses that we classified as a poor response. ${ }^{16}$ Some examples of poor responses include: charging fees where none should be charged, ${ }^{17}$ asking for notarized proof of identity, or sending the wrong information. Table 2 provides examples of agencies that provided low-quality responses and exceeded the 20 working day threshold for a response.

\section{[Insert Table 2 Here]}

Do structural features that enhance political responsiveness undermine democratic responsiveness? A number of different agency features are related to the degree of influence exerted by elected officials. One obvious measure is the number of appointees relative to the number of employees. To measure the degree of politicization we use the percentage of agency

\footnotetext{
${ }^{16}$ Two responses were classified as poor responses even though no official response was provided. Each contact for clarification pauses the agency's statutorily-mandated 20 days to respond, and the pause is ended by the requestor's clarification. Most calls seemed to be made in good faith, rather than as an attempt to delay. One message we received, however, was rather overt. The FOIA officer stated that she would be out of town, and that we should return the call after she returned, but we (emphatically) should not leave a voicemail, presumably because our voicemail would "re-start the clock" on the agency's response time. This was coded as a poor response. Another poor response that was not a response was from an agency complaining that what we were asking was a lot of work but not actually ever filling the request. For the analyses that follow we look only at the cases where a response was provided by the agency where the agency had records responsive to our request.

${ }^{17}$ Since the persons sending the requests were educational requesters, no fee should be charged under FOIA.
} 
employees that are appointed $* 100 .{ }^{18} \mathrm{We}$ also examine general differences in agency design. Agencies can be loosely grouped into agencies in the Executive Office of the President (EOP; 0,1), the Cabinet $(0,1)$, independent administrations $(0,1)$, and independent commissions $(0,1) .{ }^{19}$ Agencies in the EOP and cabinet should be more responsive to political appointees and elected officials than agencies designed to be insulated from their influence such as independent commissions. Using these different features of agency design should give us a nice picture since neither politicization nor the general categorization of agencies is a perfect measure of responsiveness to elected officials. For example, the number of appointees is not a perfect measure of responsiveness since commissions have numerous appointees but their party balancing requirements and fixed and staggered terms are intended to insulate them from political influence.

The location of FOIA officers also varies across agencies and is unrelated to the number of appointees in an agency. ${ }^{20}$ FOIA officers are found in political offices, like the office of the secretary; legal offices, like the general counsel; and more public-oriented offices, like the office of information or the office of communication. FOIA officers are also found in management directorates. Including an indicator for location of the FOIA office in the executive secretariat provides a means of evaluating how proximity to political appointees influences FOIA office

\footnotetext{
${ }^{18}$ More specifically, in the full models we use $\ln (1+((\#$ Senate confirmed positions + \#non-career SES + \#Schedule C)/\#employees March 2011))) *100. We collected the number of Senate-confirmed positions from the 2008 Plum Book and the other data from March 2011 data from OPM's Fedscope website (http://www.fedscope.opm.gov/, last accessed June 11, 2011). The mean of the raw percentages of appointees is 0.70 and the standard deviation is 0.91 ( $\min 0$, max 3.74). Since this variable is skewed significantly toward 0 we include the natural $\log$ of this number.

${ }^{19}$ Independent commissions include all agencies outside the EOP or cabinet that are commissions. This differs from the group of independent regulatory commissions, a group which commonly includes the Commodity Futures Trading Commission, Consumer Product Safety Commission, Equal Employment Opportunity Commission, Federal Communications Commission, Federal Trade Commission, National Labor Relations Board, Nuclear Regulatory Commission, and Securities and Exchange Commission.

${ }^{20}$ Additionally, some FOIA officers fill FOIA requests all day, while others have other roles they perform within the agency. Extensive research into the history of FOIA offices and fulfillment revealed longstanding variation in responsiveness across agencies since the early days of FOIA (Gianella, 1971; Nader, 1970), but we have found no evidence that the location of FOIA was consciously chosen for political reasons or in response to good or bad performance early on (Clark, 1967; Wozencraft, 1967; Gianella, 1970).
} 
performance. If locating a FOIA office in the secretariat politicizes the FOIA process, then mechanisms like generic management challenges, caused in part by micromanagement and increased layers of review, could be at play.

In Figure 1 we graph the average response times by type of request and by high (top 25\%) and low politicization (bottom 75\%) agencies. As expected, agencies took longer to fill our politically sensitive requests. The slower response time for the sensitive request may be due to increased search time required to find out whether appointees were involved in reviewing different requests or because of the mechanisms we propose, such as increased review and scrutiny from public officials of the sensitive requests, though as we demonstrate through regression analysis, the location of the FOIA office seems to be at play as well. ${ }^{21}$ The figure also shows that agencies with high percentages of appointees were slightly slower to respond to our politically-sensitive requests than agencies with lower percentages of appointees. Interestingly, however, they were quicker to respond to the baseline request. The different treatment of baseline and sensitive requests by high politicization agencies suggests a systematically different treatment of the politically sensitive requests.

\section{[Insert Figure 1 here.]}

We also graph the average confirmation and response times by differences in agency design (Figure 2). The figure indicates that agencies in the Executive Office of the President (EOP) and Cabinet were the slowest to confirm our requests and independent administrations were the quickest, though the differences are not large for a simple confirmation. Agencies that are the most politicized were the slowest to confirm that they received our FOIA requests. Cabinet and EOP agencies were again the slowest responding to our requests, followed by

\footnotetext{
${ }^{21}$ The number of appointees has almost no correlation with the politicization score (corr $=-0.0675$ ), so we find this threat to be unlikely. This is especially true because our accelerated failure time model, presented below, shows the biggest effect for FOIA offices located in the secretariat.
} 
independent commissions and other independent agencies. ${ }^{22}$ Agencies designed to be most responsive to political principals, those in the EOP and cabinet, were the slowest in responding to citizen requests for information.

\section{[Insert Figure 2 here.]}

In Figure 3 we focus not on agency design but FOIA offices themselves. Figure 3 graphs confirmation and response times by the location of the FOIA office. Interestingly, agencies with FOIA offices in the Office of the Secretary or commission secretariat were quicker to confirm receipt of our request but slightly slower to respond to it. There are a number of possible explanations for this pattern. FOIA offices in the secretariat may receive the most requests and therefore best at automating responses but could also have the most political review of requests. Of course, there are other differences among agencies that may explain differences in confirmation and response times which account for in fuller models of FOIA response times.

\section{[Insert Figure 3 here.]}

In total, the simple descriptive data on FOIA responses suggests that agencies designed to be the most responsive to political principals are slower at responding to citizen requests for information.

\section{Models of FOIA Response}

To account for potential confounders we begin by estimating different variations of the following simple model:

\footnotetext{
22 The pattern is slightly different if we break up EOP and Cabinet agencies. Agencies in the EOP appear to have filled our requests the quickest. Caution is necessary in interpreting the response times from EOP agencies, however, since there are only five EOP agencies subject to FOIA. Four responded to our request and in most of the cases, their response indicated that they had no records responsive to our request. When there are no records responses tend to be quicker. If we exclude the "no records" responses, the pattern looks more similar to the pattern of agency confirmation times.
} 


$$
\mathrm{Y}_{\mathrm{a}}=\alpha+\beta \mathrm{X}_{\mathrm{a}}+\phi \mathrm{p}_{\mathrm{a}}+\gamma \mathrm{R}_{\mathrm{a}}+\delta\left(\mathrm{R}_{\mathrm{a}} * \mathrm{p}_{\mathrm{a}}+\varepsilon\right.
$$

for agency a, where $\mathrm{Y}_{\mathrm{a}}$ is the number of days it takes an agency to fill a FOIA request, $X_{a}$ includes agency specific controls (FOIA workload/FOIA office staff size, etc.), $\mathrm{p}_{\mathrm{a}}$ is agency politicization, $\mathrm{R}_{\mathrm{a}}$ is request type (baseline or sensitive), and $\varepsilon$ is random error. Specifically, the models include controls for the log of the number of agency employees (mean 7.52; SD 2.63) ${ }^{23}$ and FOIA office workload. We measure the latter as the number of requests per FOIA staff person or, more specifically the \# FY 2010 agency FOIA requests/\# staff working in the FOIA office $(153 ; \min 0, \max 844){ }^{24}$

Given our interest in whether agencies designed to be responsive to elected officials are particularly slower in responding to politically sensitive requests, we also estimate models of the differences between the baseline and sensitive request. In these models we include similar controls except we also control for the number of appointees since the difference between baseline and sensitive may be larger for agencies where there are a lot of appointees due simply to the search time required. Specifically, we estimate:

$$
Y_{\text {sens,a }}-Y_{\text {base }, a}=\alpha+\beta X_{a}+\phi p_{a}+\varepsilon
$$

for agency a, where $\alpha$ is the average difference in time of response between the baseline and sensitive requests, $X_{a}$ again includes agency specific controls, $\mathrm{p}_{\mathrm{a}}$ is agency politicization, and $\varepsilon$ is random error. In models of differences, $\beta$ is how much worse or better an agency is at

\footnotetext{
${ }^{23}$ The number of agency employees varies from 10 to 314,066. Given the skew and the possibility of influence by the extreme values, we include the log. The main results are robust to the way we control for agency employment.

${ }^{24}$ Source: http://www.foia.gov/, last accessed June 11, 2011. One former FOIA officer we spoke to noted that in some agencies Privacy Act and FOIA requests are handled together and in other agencies they are handled separately and that in the former type of agency they might respond slower. In response to this suggestion we read each agency confirmation and response letter for an indication that the office also handled Privacy Act requests such as title of official, name of office, mention of the Privacy Act in the letter, etc. When models were estimated with this control, they had no effect on the key findings. Notably, however, FOIA offices that handled Privacy Act cases were marginally more likely to claim exemptions $(\mathrm{p}<0.16)$.
} 
responding to a sensitive request based upon agency specific features. $\phi$ is how much better or worse more politicized agencies are in responding to sensitive requests.

\section{RESULTS}

Do structural features that enhance political accountability undermine democratic accountability? In Table 3 we include estimates from Accelerated Failure Time (AFT) models of the time it took for agencies to confirm or fill FOIA requests. ${ }^{25}$ A positive coefficient indicates that it took agencies a longer time to respond to the FOIA requests. ${ }^{26} \mathrm{We}$ include three models of both confirmation and filling. The first and fourth models include very conservative specifications without measures of politicization or FOIA office workload. We do this because it was impossible for us to get data on politicization and FOIA office details for some of the agencies in our dataset. $^{27}$

\section{[Insert Table 3 here.]}

In the models that measure the percentage of appointees in the agency, increasing percentages of appointees is correlated with slower response times. The higher the percentage of appointees, the longer the time it takes to fill requests. Substantively, increasing the percentage of agency employees that are appointed from the bottom quartile to the top quartile of the distribution of politicization is estimated to increase the median FOIA confirmation and response

\footnotetext{
${ }^{25}$ We estimate a generalized gamma model since this allows for a flexible hazard rate and had the best fit according to the Akaike Information Criterion. We have also estimated Cox proportional hazards models and the results are similar but with a few differences. While the results for the percentage of appointees are similar, we could not reject the null that agencies with FOIA offices in the secretariat and EOP and cabinet agencies are no slower to confirm or fill requests than other agencies. Notably, larger agencies were always estimated to have lower hazard rates (i.e., slower to respond) than smaller agencies.

${ }^{26}$ In Appendix $\mathrm{C}$ we include estimates from models of whether or not the agency confirmed $(0,1)$ or filled $(0,1)$ our requests at all.

27 The agencies for which we do not have politicization data include intelligence agencies such as Central Intelligence Agency and Office of the Director of National Intelligence and a few small bureaus or agencies (i.e., National Indian Gaming Commission, National Guard Bureau).
} 
times by 8-9 days. $^{28}$ This is important evidence that agencies with the features of political accountability (i.e., greater number and penetration of appointees) are actually less responsive to the public when it comes to requests for information. Features of administrative agencies that enhance political accountability may decrease direct democratic accountability. Interestingly, the interaction between request type and appointee percentage suggests that the effect of politicization on FOIA confirmation and response times is smaller for sensitive requests. This may be due to the fact that in many agencies no appointees reviewed any FOIA requests, which made responding to our sensitive request easy and quick. When we remove such "no records" responses, politicization is estimated to have the same effect on responsiveness to both baseline and politically sensitive requests. ${ }^{29}$

Notably, agencies in the EOP are estimated to be slower on average, once we control for a host of other agency and FOIA office characteristics. This effect is not robust for the Cabinet. The estimates for the EOP agencies suggest that EOP agencies take about 30 days longer to confirm and fill a request. EOP and cabinet agencies are generally designed to be the most responsive to the president and administration appointees and agencies in these locations are estimated to be slower than independent agencies in confirming and filling requests.

When FOIA offices are placed in the Office of the Secretary rather than management offices, general counsels' offices, or public affairs offices, agencies are also estimated to confirm receipt of and respond more slowly to citizen requests by 16 to 55 days, respectively. There is a significantly higher probability that a request will be outstanding if the FOIA office is located in

\footnotetext{
${ }^{28}$ For substantive interpretation, we generate predicted median response times using the predict command in STATA with all values set at their means.

${ }^{29}$ We have also estimated models that include interactions of politically sensitive request and EOP agencies, Cabinet agencies, and FOIA office in the secretariat. The point estimates in 4 of the 6 cases are positive, indicating that sensitive requests take longer in these agencies but we could not reject the null of no effect in any of the cases. The effect of these factors on the difference between baseline and sensitive requests is dealt with in more detail in the next section.
} 
the office of the secretary, director, or chair of the commissions. That this is the case helps us to believe that it was not the logistical complication of having to track down appointees who might have intervened in FOIA requests that we introduced with our sensitive request, but instead the actual politicization of the FOIA office in the agencies that put the FOIA office in the secretariat.

Other point estimates indicate that large agencies are estimated to take longer to fill their requests although the estimates are only marginally significant in one model. The FOIA workload per FOIA employee is not correlated with the time required to respond. As expected, the sensitive request was estimated to be confirmed and filled more slowly, although the effect is not robust across the specifications. The fact that sensitive requests were estimated to be filled as quickly as our baseline requests in some cases may be the result of the fact that the responses we received to many of our sensitive requests were "no records" responses. When an agency had no appointee oversight of FOIA requests, agencies had no records to produce and could send a simple letter in response to our request rather than a more detailed set of records. These responses were naturally quicker than other responses.

The time it takes an agency to respond to a FOIA request is only one measure of performance. Table 4 includes estimates of response quality, whether or not an agency claimed exemptions in filling the request or otherwise produced an inferior response to the request. These estimates are based upon fewer cases since they include only those cases that have generated a response (exemptions) or for which we are certain the agency received the request (poor response). The results here are inconclusive, generally suggesting that agencies designed to be responsive to elected officials are no more likely to claim exemptions or otherwise produce a poor response. We could not reject the null that the penetration of appointees had no influence on the number of exemptions claimed or the quality of the response if a response was sent. Agency 
location in the EOP or Cabinet also had no discernible influence on the content of responses. The coefficients do, however, indicate that responses from FOIA offices in agency secretariats are more likely to produce a poor response. Substantively, FOIA offices in agency secretariats are estimated to be 19 percentage points more likely to charge fees, provide material we did not ask for while not providing the requested material, or otherwise produce a poor response. Interestingly, point estimates suggest that such agencies are estimated to be less likely to claim exemptions to FOIA requests, although we cannot reject the null of no effect.

Other coefficient estimates suggest that overworked agencies - agencies with a large number of requests per FOIA staff person - are the most likely to produce a poor response. Increasing the ratio of requests to FOIA staff by one standard deviation is estimated to increase the probability of a poor response from 0.21 to 0.29 . Interestingly, the responses to our baseline request were significantly more likely to lead to exemptions or poor responses despite the fact that our sensitive request was both less common and more complicated. While the evidence suggests having FOIA offices close to political officials may lead to poorer responses, it is also the case that the sheer size of the task and relative workload influence the quality of the responses.

One difficulty in the analysis of response quality is that a large percentage of responses (69/87) to our sensitive request were "no records" responses which are impossible to evaluate as low or high quality since it is hard to evaluate response quality when the agency has no records to send. In such cases agencies also do not claim exemptions because there are no records to redact. The analysis of the response quality, then, was largely an analysis of the baseline request responses. This may explain the apparent decreased influence of the political factors. The most 
sensitive requests may take longer to review and fill but there are fewer records to send and evaluate for quality.

\section{[Insert Table 4 here.]}

In total, the analysis of timing with controls suggests a robust relationship between whether or not the agency has the features we associate with political accountability and a lack of responsiveness to FOIA requests. Agencies designed to be responsive to political principals are slower to confirm or fill requests even when controlling for agency size and workload. There is little evidence in the full dataset, however, that these agencies are more likely to claim exemptions or respond poorly when they do respond. What evidence there is, suggests that agencies with FOIA offices in their secretariats and agencies with overworked FOIA staffs are the most likely to produce a response that is less satisfactory to the requester (i.e., produce a poor quality response). Interestingly, when we subset to just the baseline requests (not shown), we see a statistically significant increase in the likelihood of a poor response as agency politicization increases, and a statistically significant decrease in the likelihood of a poor response among independent agencies. $^{30}$

One of the virtues in our research design was its ability to speak to whether agencies designed to be responsive to political principals would be less responsive to public requests for information and perhaps particularly less responsive to requests for politically sensitive information. This is why we sent a baseline (control) and sensitive (treatment) request to each agency. Is the difference in responsiveness between the baseline and politically sensitive requests larger for the agencies that are more political? In Table 5 we include estimates from a regression on the differences in time to confirm and fill sensitive and baseline requests. These models

\footnotetext{
${ }^{30}$ The baseline requests were less likely to have responses of "no records responsive" than the sensitive requests, leaving open the possibility of exemptions and poor quality responses that "no records responsive" responses do not allow.
} 
include the same controls as those in Table 3. A positive coefficient implies that the independent variable is correlated with the agency being slower in response to the politically sensitive requests.

\section{[Insert Table 5 here.]}

As the model estimates suggest, we cannot reject the null that agencies designed to be responsive to political principals are no worse at responding at politically sensitive requests for information. The models do not improve on a constant-only model and the coefficient estimates are imprecise. While the coefficient estimate on the percentage of appointees is positive, suggesting such agencies are slower in responding to politically sensitive requests, we could not reject the null that such agencies are no slower with the politically sensitive requests. Interestingly, once we control for the percentage of appointees, agencies with more appointees (i.e., higher workload to fill the request) are estimated to respond more quickly to the politically sensitive request. Independent agencies were faster to confirm and respond to the sensitive request than the baseline request, a statistically significant finding in both models.

The evidence from Table 5 combined with the previous findings help illuminate why more politicized agencies are slower at responding to citizen requests for information. There were three possible mechanisms that would explain why more politicized agencies would be less responsive to citizen requests for information. The first was that agencies with lots of appointees would purposefully want to hide or delay releasing information, particularly politically sensitive information, and add obstacles to citizens seeking information. The second was that a focus on political priorities would crowd out attention dedicated to lower priority tasks such as FOIA requests. The final mechanism was that more politicized agencies would be troubled with generic management problems associated with political intervention such as high management turnover 
among executives and lower levels of executive competence. There is persuasive evidence that agencies designed to be responsive to elected officials are the slowest in responding to requests for information even when controlling for a host of factors. There is little evidence, however, that they are more aggressive at claiming exemptions or frustrating requesters with fees. Similarly, there is little evidence that more politicized agencies are particularly slow with the politically sensitive requests. In other words, there is no evidence that agencies designed to be responsive to political principals are less responsive to the public because of added layers of review or purposeful delay. Instead, difficulties in responding appear to be due to poor performance of the FOIA offices, either because political actors focus more on other agency activities or because of poorer management agency-wide.

\section{RESPONSIVENESS TO DIFFERENT PRINCIPALS}

In the above analysis, we test differences in responsiveness to the public between high and low politicization agencies. In that analysis we evaluated agency responsiveness to the public directly. One reasonable expectation, derived from the existing literature, is that high politicization agencies should be more responsive to political principals than they are to the public. Of course, if more politicized agencies suffer from poorly run FOIA offices or other generic management challenges, they are likely to have difficulties responding either to the public directly or political principals. An excellent opportunity to test this view presented itself as we received responses to FOIA requests we made for a different project.

Since gaining the chairmanship of the House Committee on Oversight and Government Reform, Rep. Darrell Issa (R-CA) has emphasized his interest in ensuring agency responsiveness to Freedom of Information Act Requests. The most visible of his efforts in this regard was a 
request sent to 107 agencies about FOIA in January 2011. Specifically, Rep. Issa asked agencies for copies of agency FOIA logs from 2006 to 2011. This request is identical to the baseline request we sent agencies four months later except that Rep. Issa was asking for significantly more data than we did. This means that by the time we sent our requests on May 9, 2011, Rep. Issa had already requested the same material from each agency. ${ }^{31}$

The House Committee on Oversight and Government Reform recorded the responses to these requests and generously provided us the data. All agencies were more responsive to Rep. Issa than to us. Among the agencies that Rep. Issa sent to, we received FOIA logs from $85 \%$ of agencies after 365 days and Rep. Issa received responses from 87\% of agencies within 95 days. The average time to respond to Rep. Issa's requests was 29 days, whereas the average time to respond to our baseline request was 87 days. As is expected and appropriate in a democracy that designs agencies to be responsive to political principals, the agencies were more responsive to Rep. Issa's request. However, they were less responsive to an identical request from private citizens (us). This is particularly interesting since these 107 agencies had received a request that encompassed the information we requested a few months previous.

Further, we examine whether more "political" agencies were more responsive to Rep. Issa's request than less "political" agencies. The answer generally is no. While agencies are

\footnotetext{
${ }^{31}$ We acknowledge that Rep. Issa having already "treated" the agencies with a request for a FOIA log might work as an additional treatment that was only received by 107 of the agencies, possibly violating the SUTVA assumption. Because requests for FOIA logs are extremely common, we suspect that we were not the only parties in the threeand-a-half months following Rep. Issa's requests to request the agency's FOIA log. We therefore cannot be sure that the 107 agencies are the only ones that were "pre-treated" before our requests. We further note that the 107 agencies that Rep. Issa contacted were, on average, slightly more politicized (median $=0.77$, mean $=3.62, \mathrm{SD}=7.6$ ) than the 132 agencies that we contacted (median $=0.35$, mean $=2.72, \mathrm{SD}=6.7$ ), which include his 107 agencies. When we estimate models controlling for Issa contact the results are similar but not identical. Specifically, the coefficient estimates on the percentage appointees are smaller and less precise and no longer statistically distinguishable from 0 . The coefficient estimates on agencies in the EOP and Cabinet, however, are positive and more precise, indicating that such agencies are significantly slower to confirm and respond to requests.
} 
significantly more responsive to Rep. Issa than the public, more "political" agencies are less responsive to Rep. Issa and less political agencies.

\section{[Insert Table 6 here.]}

In Table 6 we include estimates of accelerated failure time models of agency response times that mirror those of Table $3 .^{32}$ Agencies with a greater percentage of appointees are estimated to take longer in responding to Rep. Issa than those with a lesser percentage. An agency in the bottom quartile in percentage appointees is estimated to respond almost 5 days faster than an agency in the top quartile. This is particularly significant, because Rep. Issa gave the agencies a tight deadline for response. ${ }^{33}$ EOP agencies are also estimated to be a few days slower in responding than other agencies. As before, larger agencies are slower than smaller agencies and agencies with heavier FOIA workloads per FOIA employee are slower than agencies with lighter FOIA workloads per FOIA employee.

In total, all agencies are more responsive to Rep. Issa than to a public requester. Interestingly, however, structural features designed to enhance political accountability (e.g., more appointees) are correlated with slower responses to Rep. Issa. This is additional evidence that illuminates the reasons why more "political" agencies are slower to public requesters. It is not that politicized agencies are purposefully responsive to political officials and not the public. Rather, agencies that are more political are less responsive to both political principals and the public. This could be because their attention and resources are allocated to agency activities that are deemed more important than the FOIA process, even when the FOIA response is to a particularly politicized requester like Rep. Issa. Management difficulties associated with

\footnotetext{
${ }^{32}$ The models in Table 6 are Weibull models since diagnostics from the Gamma model indicated that a Weibull would be appropriate. We have also estimated Cox models that confirm what is reported in Table 6.

${ }^{33}$ He requested a response within 15 business days of the date he sent the requests (January 25 to February 15 ).
} 
political intervention into agency management create delays and non-response to both public and political requesters.

\section{DISCUSSION AND CONCLUSION}

In this paper we have called into question the assumption that responsiveness to political principals equates to democratic accountability. We have shown that, counterintuitively, the structures designed to increase agencies' political accountability correlate with decreased direct democratic accountability. While generic differences in agency location (EOP, cabinet, independent) had some influence on agency response times, agencies with more appointees as a percentage of all employees are less likely to respond and slower to respond than their counterparts with fewer appointees as a percentage of all employees. And agencies with the FOIA office in the secretariat, rather than general counsel, management, or public affairs branches of the agency, were much slower to both confirm and respond to our FOIA requests.

While distinguishing between the mechanisms at play is difficult, our results indicate that extra layers of review and other incentives for delay on political requests are unlikely to be the cause of the lack of responsiveness. Our design allowed us to examine additional delay for politically sensitive requests, which are exactly the kind of request we would expect the extra layers to affect. But we do not find that sensitive requests take longer. Similarly, we do not observe more politicized agencies claiming more exemptions to our requests. We could not rule out that the attention agencies pay to political principals crowds out attention to activities such as FOIA. While workload per FOIA employee was not a predictor of the likelihood of responding or length of time to response, agencies with higher numbers of requests per FOIA employee were more likely to produce poor responses. More generally, based on the nature of some of the slow 
responses even to confirm requests, it seems that general management challenges could impede the FOIA process. These results are consistent with past work that finds that increases in appointees damage agency management performance (Gilmour and Lewis 2006; Heclo 1977; Lewis 2008). The delays in responding to Rep. Issa's requests, while less pronounced than delays to our requests, followed a similar pattern. More politicized agencies were less able to respond to his request, because the FOIA activities are crowded out by policy work, or because of generic management challenges that come from having appointees rotating through the top of the agency structure, or both.

Our argument is limited. We recognize that the agency role in providing information is only one type of agency role, fitting in a broader context of agency activities, primary of which are rulemaking, adjudication, and policy implementation. Our measure imperfectly captures the accountability of agencies when acting in the roles of rulemaking and adjudication. Our findings show that there is variation in direct agency accountability to the people, and it should not be ignored, or assumed not to transfer to the agency roles more often examined by courts. If an agency is unaccountable in the role that is most directly associated with citizen contact, might it also be unaccountable in rulemaking or adjudication? The possibility remains, and it is highlighted by our findings.

But what does the empirical relationship between politicization and agency responsiveness to FOIA requests imply for democratic accountability? Is it possible that FOIA offices are being more democratically accountable by not responding generously to FOIA requests? Indeed, there is a long literature that describes how non-democratic institutions (e.g., courts, professional civil service) are necessary for democracy to flourish (see, e.g., Stephenson 2008). Agencies may be more democratically accountable, for example, by being more careful 
with requests that involve national security or raise privacy concerns. However, our requests had no connection to national security nor presented real privacy concerns (although this is clearly a subject of disagreement given the exemptions claimed by some agencies). They were the kinds of requests that generate information useful to citizens trying to figure out how agencies are making decisions. Indeed, it is hard to understand how agencies can be more democratically accountable, in the form courts understand it, by being less responsive to citizen requests for simple and uncontroversial information.

We also question the one-size-fits-all deference from the judiciary to agencies, at least to the extent that it is justified by agencies' greater democratic accountability as compared to the courts. Courts have long recognized variations in democratic accountability among agencies, going back at least as far as Humphrey's Executor (1935). But only more recently have justices begun to connect the variation in democratic accountability with the need for a more nuanced approach to deference. Justice Stevens' dissent in FCC v. Fox broached the subject in 2009, but no majority opinion has adopted his rationale. If deference to agency decision-making is based on the agencies' increased accountability to the people, as compared to courts' insulation, then our study helps to inform when the assumption of increased accountability is warranted and when it should be re-examined.

President Obama pledged to provide a more open government and pledged to make FOIA policies more open. While increased transparency is generally popular with the electorate, the President faces an uphill battle to improve the FOIA process, as this study shows. The structures that any president relies upon for political responsiveness correlate with less openness in government, and weaker FOIA responsiveness in particular. More politicized agencies are not more open and transparent; they are less open and transparent. 


\section{References}

Aberbach, Joel D. 1990. Keeping a Watchful Eye. Washington, DC: Brookings.

Calabresi, Steven G. 1995. "Some Normative Arguments for the Unitary Executive.” Arkansas Law Review 48:23, 58-70.

Clark, Ramsey. 1967. Attorney General's Memorandum on the Public Information Section of the Administrative Procedure Act. Available at http://www.justice.gov/oip/67agmemo.htm.

Devins, Neal, and Michael Herz. 1998. "The Battle that Never Was: Congress, the White House, and Agency Litigation Authority." Law and Contemporary Problems 61 (Winter):205.

Dodd, Lawrence C. and Richard L. Schott. 1979. Congress and the Administrative State. New York, NY: Wiley.

Fisher, Louis. 2000. Presidential Abdication on War and Spending. College Station, TX: Texas A\&M University Press.

Gailmard, Sean, and John W. Patty. 2007."Slackers and Zealots: Civil Service, Policy Discretion, and Bureaucratic Expertise." American Journal of Political Science 51:873-89.

Gianella, Donald A. 1971. "Agency Procedures Implementing the Freedom of Information Act: A Proposal for Uniform Regulations," Administrative Law Review 23(217).

Gilmour, John B., and David E. Lewis. 2006. "Political appointees and the competence of Federal Program Management.” American Politics Research 34:22-50.

Heclo, Hugh. 1977. A Government of Strangers: Executive Politics in Washington. Washington, DC: Brookings Institution Press.

Howell, William G. 2003. Power Without Persuasion: A Theory of Presidential Action. Princeton, NJ: Princeton University Press.

Kagan, Elena. 2001. "Presidential Administration.” Harvard Law Review 114:2245, 2331-37. 
Lessig, Lawrence, and Cass Sunstein. 1994. "The President and the Administration" Columbia Law Review 94:1,102-03.

Lewis, David E. 2003. Presidents and the Politics of Agency Design. Stanford, CA: Stanford University Press.

Lewis, David E. 2008. The Politics of Presidential Appointments: Political Control and Bureaucratic Performance. Princeton, NJ: Princeton University Press.

May, Randolph. 2010. "Defining Deference Down, Again: Independent Agencies, Chevron Deference, and Fox.” Administrative Law Review 62:433.

Mayer, Ken. 2000. With the Stroke of a Pen. Princeton, NJ: Princeton University Press.

McCubbins, Matthew D. and Thomas Schwartz. 1984. "Congressional Oversight Overlooked: Police Patrol Versus Fire Alarm.” American Journal of Political Science 28(1):165-177.

Moe, Terry M. 1985. The Politicized Presidency. In The New Direction in American Politics, edited by J. E. Chubb and P. E. Peterson. Washington, DC: Brookings Institution Press.

Moe, Terry M. 1989. The Politics of Bureaucratic Structure. In Can the Government Govern? edited by J. E. Chubb and P. E. Peterson. Washington, DC: Brookings Institution Press.

Nader, Ralph. 1970. "Freedom from Information: The Act and the Agencies". Harvard Civil Rights Civil Liberties Law Review 5:53.

Nathan, Richard P. 1975. The Plot that Failed: Nixon and the Administrative Presidency. New York, NY: John Wiley.

Pierce, Richard J., Jr. 1989. "The Role of the Judiciary in Implementing an Agency Theory of Government.” New York University Law Review 64:1239,1280-85.

Rubin, Donald B. 1990 . "Formal Modes of Statistical Inference For Causal Effects." Journal of Statistical Planning and Inference. 25:279-292. 
Stephenson, Matthew. 2008. "Optimal Political Control of the Bureaucracy." Michigan Law Review 107:53-110.

Stephenson, Matthew. 2011. "Information Acquisition and Institutional Design." Harvard Law Review 124:1422-1483.

Van Thiel, Sandra, and Frans L. Leeuw. 2002. "The Performance Paradox in the Public Sector." Public Performance \& Management Review 25(3):267-281.

Wood, B. Dan, and John Bohte. 2004. "Political Transaction Costs and the Politics of Administrative Design.” Journal of Politics 68(1):176-202.

Wood, B. Dan, and Richard W. Waterman. 1994. Bureaucratic Dynamics: The Role of Bureaucracy in a Democracy. Boulder, CO: Westview Press.

Wozencraft, Frank M. 1967. "The Freedom of Information Act - The First 36 Days." Administrative Law Review 20(249). 
Figure 1. Average Days to Fill Baseline and Sensitive Requests by Politicization

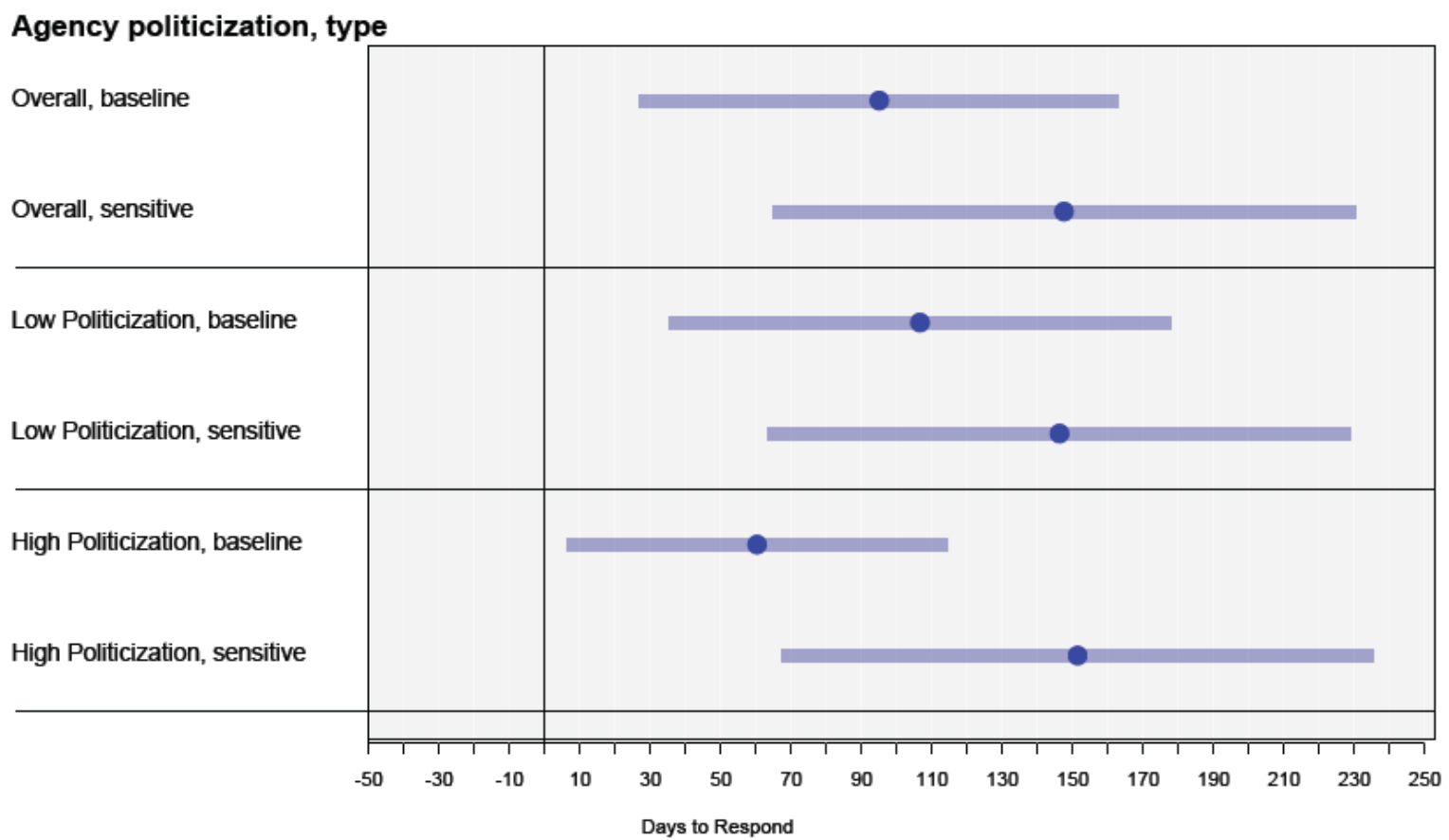

Note: High politicization agencies in top $25 \%$ of agencies in terms of percentage of appointees vs. employees. The points are the means among each group, and the purple lines are one standard deviation around the mean. 


\section{Figure 2. Average Days to Confirm and Fill FOIA Requests by Agency Type}

Time to Confirm Receipt of FOIA Request

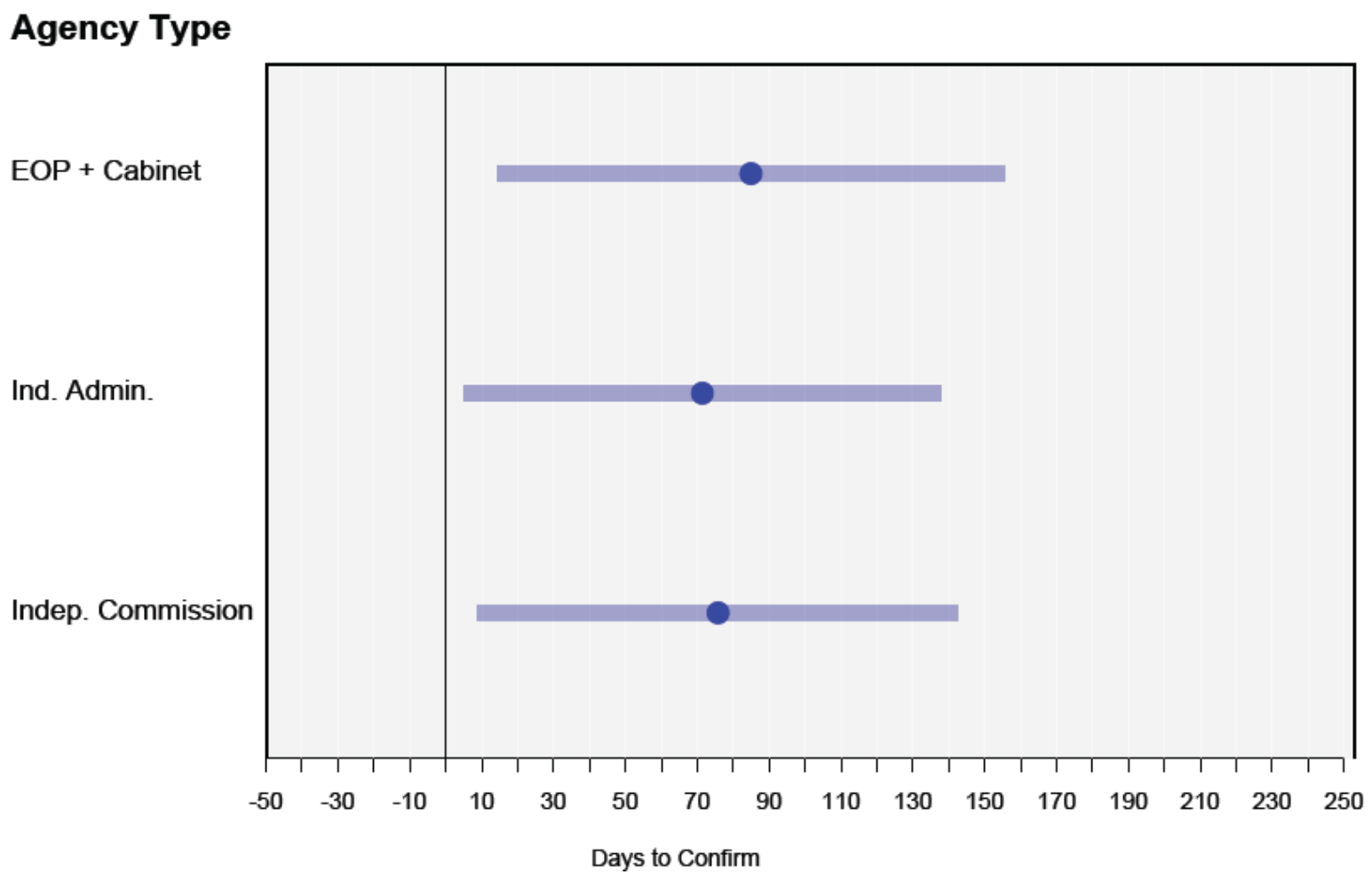

Time to Fill FOIA Request

\section{Agency Type}

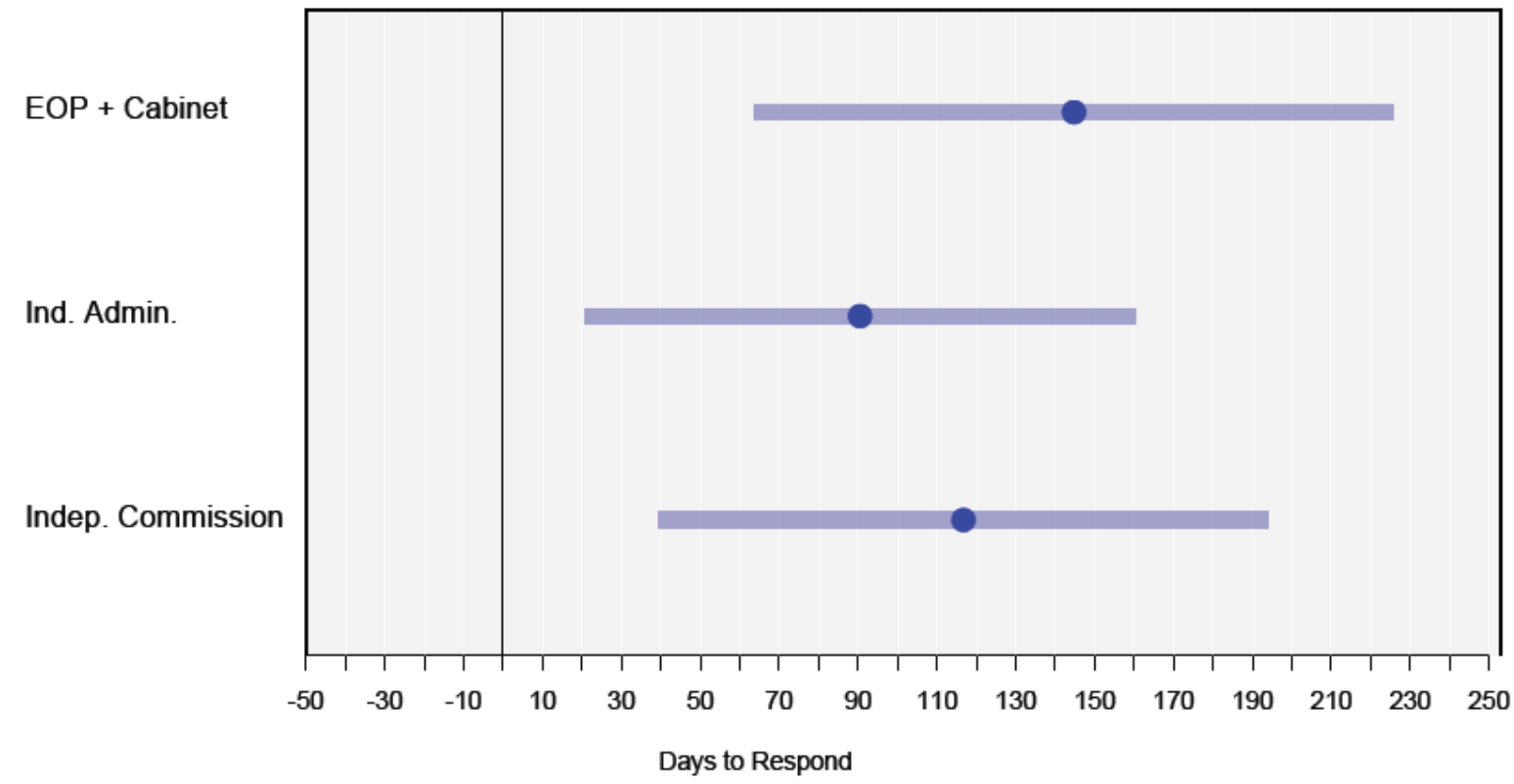

Note: The points are the means among each group, and the purple lines are one standard deviation around the mean. Independent Commissions include independent regulatory commissions. 
Figure 3. Average Days to Confirm and Fill FOIA Requests by FOIA Office Location

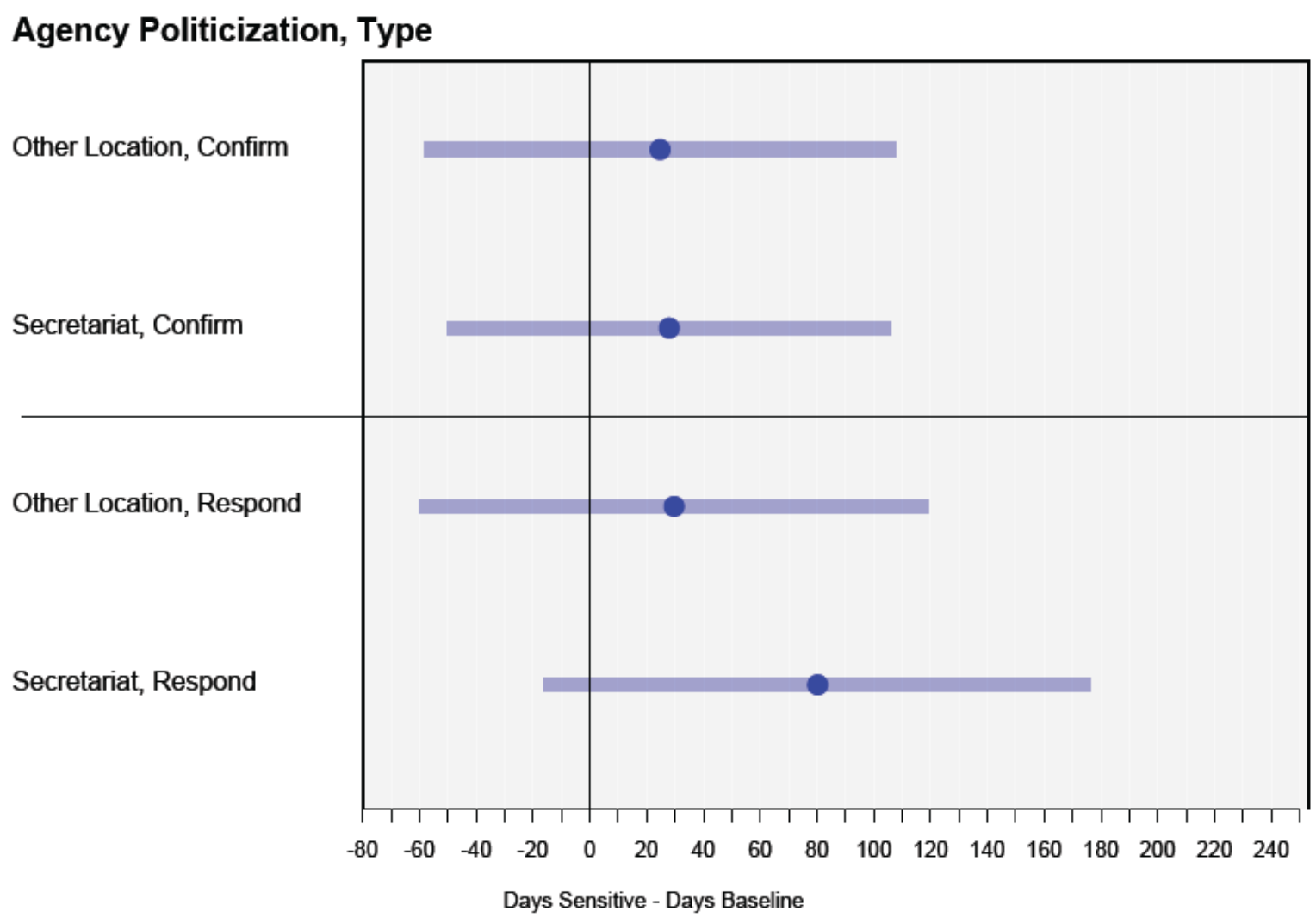

Note: The "Other" category includes the management office, general counsel's office, office of public affairs, office of policy coordination and information, office of special counsel, chief financial officer, and office of hearings and appeals. The points are the means among each group, and the purple lines are one standard deviation around the mean. 
Table 1. Agencies that Never Responded to Either Baseline or Sensitive Request

\begin{tabular}{|c|c|c|c|}
\hline Agency & $\begin{array}{l}\text { Agency Confirmed } \\
\text { Receipt of Our } \\
\text { Request }\end{array}$ & Cabinet & $\begin{array}{l}\text { Total } \\
\text { Appointees }\end{array}$ \\
\hline Bureau of Customs and Border Protection (DHS) & $\mathrm{NO}$ & YES & 9 \\
\hline Court Services and Offender Supervision Agency & NO & NO & 0 \\
\hline Department of Energy & NO & YES & 116 \\
\hline Department of Justice & NO & YES & 346 \\
\hline Federal Energy Regulatory Commission (DOE) & NO & YES/ NO & 9 \\
\hline Federal Housing Finance Agency & NO & NO & 4 \\
\hline Federal Maritime Commission & YES & NO & 8 \\
\hline Federal Mine Safety and Health Review Commission & NO & NO & 9 \\
\hline Missile Defense Agency (DOD) & NO & YES & 0 \\
\hline National Geospatial-Intelligence Agency (DOD) & YES & YES & $*$ \\
\hline Office of Personnel Management & YES & NO & 29 \\
\hline Public Health Service (HHS) & YES & YES & $*$ \\
\hline Transportation Security Administration (DHS) & YES & YES & 1 \\
\hline
\end{tabular}

Note: While the Federal Energy Regulatory Commission is statutorily located in the Department of Energy, its fixed terms and for cause removal protections means it operates more like an independent agency. 
Table 2. Examples of Agencies that Produced Poor Responses and Exceed Statutory Time to Respond

\begin{tabular}{|c|c|c|c|}
\hline Agency & $\begin{array}{l}\text { Request } \\
\text { Type }\end{array}$ & $\begin{array}{l}\text { Days to } \\
\text { Respond }\end{array}$ & Description of Response \\
\hline Federal Maritime Commission & Baseline & 365 & $\begin{array}{l}\text { Called and said needed to talk about all requests, } \\
\text { asked us not to call back because she would be out of } \\
\text { the office, refused to say when she was returning. }\end{array}$ \\
\hline U.S. Citizenship \& Immigration Services & Sensitive & 365 & Asked for proof of identification. \\
\hline Centers for Medicare \& Medicaid Services & Baseline & 365 & $\begin{array}{l}\text { Only response was letter suggesting it was a lot of } \\
\text { work. }\end{array}$ \\
\hline Commodity Futures Trading Commission & Sensitive & 190 & Multiple duplicate responses mailed \\
\hline National Reconnaissance Office & Baseline & 81 & Only part of 2010 , fees charged \\
\hline Comptroller of the Currency & Baseline & 77 & Fiscal year rather than calendar year. \\
\hline Agency for International Development & Baseline & 73 & Fiscal year rather than calendar year. \\
\hline Corporation for National Service & Baseline & 51 & Only part of 2010 included in response. \\
\hline Pension Benefit Guaranty Corporation & Baseline & 49 & $\begin{array}{l}\text { Fiscal year rather than calendar year. Nice CD and } \\
\text { Fed Ex Mailer }\end{array}$ \\
\hline Equal Employment Opportunity Commission & Baseline & 48 & Summary statistics only. \\
\hline
\end{tabular}

Note: If we assume it took our letters 2 weeks to arrive at the agency FOIA office, 20 working days would charitably be June 20, 2011, or 42 calendar days after our request. This table includes every poor responder that took longer than 42 calendar days. It excludes those agencies that never responded. This table also excludes agencies that charged us fees. Every agency is required to keep a FOIA log and agencies are obligated to fill educational requests without fees. 
Table 3. Accelerated Failure Time Models of FOIA Responses: Politicization and Time to Confirm or Fill FOIA Requests

\begin{tabular}{|c|c|c|c|c|c|c|}
\hline & $\begin{array}{l}\text { Confirm } \\
\text { (Coef.) } \\
\text { (S.E.) } \\
\end{array}$ & $\begin{array}{l}\text { Confirm } \\
\text { (Coef.) } \\
\text { (S.E.) } \\
\end{array}$ & $\begin{array}{l}\text { Confirm } \\
\text { (Coef.) } \\
\text { (S.E.) } \\
\end{array}$ & $\begin{array}{l}\text { Respond } \\
\text { (Coef.) } \\
\text { (S.E.) }\end{array}$ & $\begin{array}{l}\text { Respond } \\
\text { (Coef.) } \\
\text { (S.E.) }\end{array}$ & $\begin{array}{l}\text { Respond } \\
\text { (Coef.) } \\
\text { (S.E.) } \\
\end{array}$ \\
\hline \multicolumn{7}{|l|}{ Politicization } \\
\hline $\ln$ (Appointees/Employees)*100 & & $\begin{array}{c}0.19 \\
(0.12)\end{array}$ & $\begin{array}{l}0.37 * * \\
(0.12)\end{array}$ & & $\begin{array}{l}0.28 * * \\
(0.13)\end{array}$ & $\begin{array}{l}0.40 * * \\
(0.12)\end{array}$ \\
\hline \multirow{2}{*}{$\begin{array}{l}\ln (\text { Appointees/Employees }) * 100 * \\
\text { Politically sensitive request }\end{array}$} & & & $-0.25 * *$ & & & -0.20 \\
\hline & & & $(0.13)$ & & & $(0.14)$ \\
\hline \multirow[t]{2}{*}{ FOIA office in Secretariat $(0,1)$} & $0.69 * *$ & $0.71 * *$ & $0.71 * *$ & $0.93 * *$ & $1.00 * *$ & $1.00 * *$ \\
\hline & $(0.13)$ & $(0.14)$ & $(0.13)$ & $(0.20)$ & $(0.19)$ & $(0.25)$ \\
\hline \multicolumn{7}{|l|}{ Agency Characteristics } \\
\hline \multirow[t]{2}{*}{$\operatorname{EOP}(0,1)$} & $1.04 * *$ & $0.74 * *$ & $0.58 * *$ & $0.86 * *$ & 0.48 & $0.43^{*}$ \\
\hline & $(0.19)$ & $(0.23)$ & $(0.15)$ & $(0.26)$ & $(0.31)$ & $(0.25)$ \\
\hline \multirow[t]{2}{*}{ Cabinet $(0,1)$} & 0.22 & 0.24 & 0.22 & 0.29 & 0.14 & 0.14 \\
\hline & $(0.18)$ & $(0.23)$ & $(0.21)$ & $(0.23)$ & $(0.34)$ & $(0.33)$ \\
\hline \multirow[t]{2}{*}{ Ind. Admin. $(0,1)$} & -0.11 & -0.05 & -0.10 & -0.09 & -0.01 & -0.02 \\
\hline & $(0.16)$ & $(0.15)$ & $(0.14)$ & $(0.23)$ & $(0.23)$ & $(0.22)$ \\
\hline \multirow[t]{2}{*}{$\ln$ (Agency Employment) } & & 0.01 & 0.02 & & $0.09 *$ & 0.08 \\
\hline & & $(0.04)$ & $(0.04)$ & & $(0.05)$ & $(0.05)$ \\
\hline \multicolumn{7}{|l|}{ FOIA Office Details } \\
\hline \multirow{2}{*}{\multicolumn{2}{|c|}{$\begin{array}{l}\text { Number of FOIA Requests FY } \\
2010 \text { / \# FOIA Employees FY } 2010\end{array}$}} & -0.00 & -0.00 & & -0.00 & -0.00 \\
\hline & & $(0.00)$ & $(0.00)$ & & $(0.00)$ & $(0.00)$ \\
\hline \multirow[t]{2}{*}{ Politically Sensitive Request $(0,1)$} & 0.03 & -0.02 & $0.15^{*}$ & 0.07 & 0.08 & $0.22 * *$ \\
\hline & $(0.06)$ & $(0.07)$ & $(0.08)$ & $(0.08)$ & $(0.11)$ & $(0.10)$ \\
\hline \multirow[t]{2}{*}{ Constant } & $1.95 * *$ & $1.82 * *$ & $1.60 * *$ & $2.25 * *$ & $1.65 * *$ & $1.53 * *$ \\
\hline & $(0.17)$ & $(0.33)$ & $(0.38)$ & $(0.23)$ & $(0.36)$ & $(0.37)$ \\
\hline \multirow[t]{2}{*}{$\kappa$} & $-2.42 * *$ & $-2.32 * *$ & $-2.55 * *$ & $-2.42 * *$ & $-2.17 * *$ & $-2.28 * *$ \\
\hline & $(0.30)$ & $(0.27)$ & $(0.40)$ & $(0.32)$ & $(0.29)$ & $(0.36)$ \\
\hline \multirow[t]{2}{*}{$\sigma$} & $0.78 * *$ & $0.78 * *$ & $0.72 * *$ & $1.11 * *$ & $1.12 * *$ & $1.08 * *$ \\
\hline & $(0.07)$ & $(0.06)$ & $(0.07)$ & $(0.09)$ & $(0.09)$ & $(0.10)$ \\
\hline $\mathrm{N}$ & 246 & 224 & 224 & 246 & 224 & 224 \\
\hline \# Confirming or filling & 203 & 187 & 187 & 181 & 169 & 169 \\
\hline LR Test $(5,8,9 \mathrm{df})$ & $54.85 * *$ & $65.29 * *$ & $83.99 * *$ & $31.76 * *$ & $57.32 * *$ & $66.81 * *$ \\
\hline
\end{tabular}


Table 4. Models of FOIA Response Quality

\begin{tabular}{|c|c|c|}
\hline & $\begin{array}{l}\text { Exemptions } \\
\text { (Coef.) } \\
\text { (S.E.) }\end{array}$ & $\begin{array}{l}\text { Poor Response } \\
\text { (Coef.) } \\
\text { (S.E.) }\end{array}$ \\
\hline \multicolumn{3}{|l|}{ Politicization } \\
\hline $\ln ($ Appointees/Employees) $* 100$ & $\begin{array}{l}-0.09 \\
(0.32)\end{array}$ & $\begin{array}{c}0.00 \\
(0.31)\end{array}$ \\
\hline FOIA office in Secretariat $(0,1)$ & $\begin{array}{l}-1.03 \\
(0.70)\end{array}$ & $\begin{array}{l}0.97 * * \\
(0.48)\end{array}$ \\
\hline \multicolumn{3}{|l|}{ Agency Characteristics } \\
\hline $\operatorname{EOP}(0,1)$ & $\begin{array}{l}0.35 \\
(0.74)\end{array}$ & -- \\
\hline Cabinet $(0,1)$ & $\begin{array}{l}-0.53 \\
(0.45)\end{array}$ & $\begin{array}{l}-0.45 \\
(0.51)\end{array}$ \\
\hline Ind. Admin. $(0,1)$ & $\begin{array}{l}-0.13 \\
(0.44)\end{array}$ & $\begin{array}{l}-0.59 \\
(0.50)\end{array}$ \\
\hline $\ln ($ Agency Employment) & $\begin{array}{c}0.13 \\
(0.10)\end{array}$ & $\begin{array}{c}0.11 \\
(0.10)\end{array}$ \\
\hline Agency Manages Benefits Programs & $\begin{array}{c}0.58 \\
(0.40)\end{array}$ & -- \\
\hline \multicolumn{3}{|l|}{ FOIA Office Details } \\
\hline $\begin{array}{l}\text { Number of FOIA Requests FY } 2010 \text { / \# } \\
\text { FOIA Employees FY } 2010\end{array}$ & $\begin{array}{l}-0.00 \\
(0.00)\end{array}$ & $\begin{array}{l}0.003 * * \\
(0.001)\end{array}$ \\
\hline Politically Sensitive Request $(0,1)$ & -- & $\begin{array}{l}-0.89 * * \\
(0.44)\end{array}$ \\
\hline Issa Requested FOIA Log & -- & -- \\
\hline Constant & $\begin{array}{l}-1.60 * \\
(0.95)\end{array}$ & $\begin{array}{l}-2.08 * * \\
(0.85)\end{array}$ \\
\hline $\begin{array}{l}\mathrm{N} \\
\text { LR Test }(8,7 \mathrm{df})\end{array}$ & $\begin{array}{c}108 \\
9.82\end{array}$ & $\begin{array}{l}164 \\
16.63 * *\end{array}$ \\
\hline
\end{tabular}

Note: **significant at the 0.05 level; *significant at the 0.10 level in two-tailed tests. Robust standard errors, clustered at agency level, reported in parentheses. Models of exemptions include only those cases where there was a response that provided records (i.e., excludes "no records" responses). There was only 1 case where a response to a sensitive request included exemptions and so that variable is excluded. There were no cases where any of the five EOP agencies produced poor responses, so they perfectly predict the outcome and are excluded. We exclude models with interactions with request type since agencies only claimed exemptions in 3 cases to sensitive requests. In the models of poor responses we could not reject the null that request type did not influence the effect of the percentage of appointees. Base category is an independent commission receiving a baseline request with a FOIA office outside the office of the secretary, administrator, director, or commission chair. 
Table 5. Models of Differences FOIA Response Times

$\begin{array}{ll}\Delta \text { Days to Confirm } & \Delta \text { Days to Fill } \\ \text { Request } & \text { Request }\end{array}$

\begin{tabular}{lcc}
\hline Politicization & & \\
$\ln$ (Appointees/Employees)*100 & 33.18 & 15.61 \\
& $(29.23)$ & $(28.30)$ \\
FOIA office in Secretariat $(0,1)$ & $-58.15^{*}$ & -17.81 \\
& $(30.44)$ & $(33.13)$ \\
Agency Characteristics & & \\
EOP $(0,1)$ & 58.13 & 13.80 \\
& $(40.76)$ & $(34.83)$ \\
Cabinet $(0,1)$ & -24.32 & -31.53 \\
& $(31.10)$ & $(49.76)$ \\
Ind. Admin. (0,1) & $-64.11^{* *}$ & $-108.35^{* *}$ \\
& $(19.91)$ & $(17.05)$ \\
ln(Agency Employment) & $12.42^{* *}$ & 3.98 \\
& $(4.54)$ & $(7.35)$ \\
\# Appointees & $-26.96^{* *}$ & -5.85 \\
& $(11.46)$ & $(12.32)$ \\
FOIA Office Details & & \\
Number of FOIA Requests FY 2010 / \# FOIA & -0.04 & -0.04 \\
Employees FY 2010 & $(0.05)$ & $(0.10)$ \\
Constant & 4.57 & 69.03 \\
& $(60.39)$ & $(63.67)$ \\
\hline N & & 112 \\
$\mathrm{R}^{2}$ & 112 & 0.07 \\
\hline Not Mods esimat & 0.07 & \\
\hline
\end{tabular}

Note: Models estimated with ordinary least squares. ${ }^{* *}$ significant at the 0.05 level; *significant at the 0.10 level in two-tailed tests. Robust standard errors, clustered at department level, reported in parentheses. 
Table 6. Accelerated Failure Time Models of Responses to Issa Request

\begin{tabular}{|c|c|c|}
\hline & $\begin{array}{l}\text { Response } \\
\text { (Coef.) } \\
\text { (S.E.) }\end{array}$ & $\begin{array}{l}\text { Response } \\
\text { (Coef.) } \\
\text { (S.E.) }\end{array}$ \\
\hline \multicolumn{3}{|l|}{ Politicization } \\
\hline $\ln$ (Appointees/Employees)*100 & & $\begin{array}{l}0.09 * * \\
(0.03)\end{array}$ \\
\hline FOIA office in Secretariat $(0,1)$ & $\begin{array}{c}0.17 \\
(0.25)\end{array}$ & $\begin{array}{l}0.19 \\
(0.24)\end{array}$ \\
\hline \multicolumn{3}{|l|}{ Agency Characteristics } \\
\hline $\operatorname{EOP}(0,1)$ & $\begin{array}{l}0.47 * * \\
(0.03)\end{array}$ & $\begin{array}{l}0.34 * * \\
(0.05)\end{array}$ \\
\hline Cabinet $(0,1)$ & $\begin{array}{l}0.08 \\
(0.32)\end{array}$ & $\begin{array}{l}0.01 \\
(0.30)\end{array}$ \\
\hline Ind. Admin. $(0,1)$ & $\begin{array}{l}0.03 \\
(0.02)\end{array}$ & $\begin{array}{l}-0.00 \\
(0.01)\end{array}$ \\
\hline $\ln ($ Agency Employment) & $\begin{array}{l}0.10^{* *} \\
(0.02)\end{array}$ & $\begin{array}{l}0.12 * * \\
(0.02)\end{array}$ \\
\hline \multicolumn{3}{|l|}{ FOIA Office Details } \\
\hline $\begin{array}{l}\text { Number of FOIA Requests FY } \\
2010 \text { / \# FOIA Employees FY } 2010\end{array}$ & $\begin{array}{l}0.001 * * \\
(0.000)\end{array}$ & $\begin{array}{l}0.001 * * \\
(0.000)\end{array}$ \\
\hline Constant & $\begin{array}{l}2.62 * * \\
(0.14)\end{array}$ & $\begin{array}{l}2.41 * * \\
(0.09)\end{array}$ \\
\hline$\rho$ & $\begin{array}{l}1.14 * * \\
(0.03)\end{array}$ & $\begin{array}{l}1.14^{* *} \\
(0.03)\end{array}$ \\
\hline $\mathrm{N}$ & 88 & 88 \\
\hline \# filling & 76 & 76 \\
\hline LR Test (3 df) & $2.53 * *$ & $25.52 * *$ \\
\hline
\end{tabular}

Note: Dependent variable is $\ln$ (days to confirmation or filling of FOIA request). **significant at the 0.05 level; * significant at the 0.10 level in two-tailed tests. Robust standard errors, clustered at department level, reported in parentheses. Base category is an independent commission receiving a baseline request with a FOIA office outside the office of the secretary, administrator, director, or commission chair. 


\section{Appendix A}

Below is a list of all the agencies we included in our initial list, which we obtained from the Department of Justice. Agencies with a double asterisk $(* *)$ were excluded from all requests.

Department of Agriculture

Department of Commerce

National Oceanic and Atmospheric Administration

Department of Defense

Air Force

Army

Defense Commissary Agency (DeCA)

Defense Contract Audit Agency

Defense Contract Management Agency

Defense Finance and Accounting Service

Defense Information Systems Agency

Defense Intelligence Agency

Defense Logistics Agency

Defense Security Service

Defense Technical Information Center

Defense Threat Reduction Agency

Department of Defense Education Activity

Marine Corps

Missile Defense Agency

National Geospatial-Intelligence Agency

National Guard Bureau/JA-FOIA

National Reconnaissance Office

National Security Agency

Navy

Department of Defense Office of the Inspector General**

Office of the Secretary of Defense and Joint Staff

TRICARE Management Activity

United States Africa Command FOIA Requester Service Center**

United States Central Command FOIA Requester Service Center**

United States European Command FOIA Requester Service Center**

United States Joint Forces Command FOIA Requester Service Center**

United States Northern Command FOIA Requester Service Center**

United States Pacific Command FOIA Requester Service Center**

United States Special Operations Command FOIA Requester Service Center**

United States Southern Command FOIA Requester Service Center**
United States Strategic Command FOIA Requester Service Center**

United States Transportation Command FOIA

Requester Service Center**

Department of Education

Department of Energy

Department of Health and Human Services

Centers for Medicare \& Medicaid Services

Food and Drug Administration

National Institutes of Health

Public Health Service

Department of Homeland Security

Bureau of Customs and Border Protection

United States Citizenship and Immigration Services

United States Coast Guard

Federal Emergency Management Agency

Federal Law Enforcement Training Center

United States Immigration and Customs Enforcement

DHS Office of Inspector General**

United States Secret Service

Transportation Security Administration

US-VISIT**

Department of Housing and Urban Development

Department of the Interior

Department of Justice

Department of Labor

Department of State

Department of Transportation

Federal Aviation Administration

Department of the Treasury

Comptroller of the Currency

Internal Revenue Service

Office of Thrift Supervision

Department of Veterans Affairs

Agency for International Development

American Battle Monuments Commission

Amtrak (National Railroad Passenger Corporation)

Broadcasting Board of Governors

Central Intelligence Agency

Chemical Safety and Hazard Investigation Board

Commission on Civil Rights

Committee for Purchase from People who Are Blind or Severely Disabled 
Commodity Futures Trading Commission

Consumer Product Safety Commission

Corporation for National Service

Court Services and Offender Supervision Agency

Defense Nuclear Facilities Safety Board

Environmental Protection Agency

Equal Employment Opportunity Commission

Council on Environmental Quality

Office of Management and Budget

Office of National Drug Control Policy

Office of Science and Technology Policy

Office of the United States Trade Representative

Export-Import Bank

Farm Credit Administration

Farm Credit System Insurance Corporation

Federal Communications Commission

Federal Deposit Insurance Corporation

Federal Election Commission

Federal Energy Regulatory Commission

Federal Financial Institutions Examination Council

Federal Housing Finance Agency

Federal Labor Relations Authority

Federal Maritime Commission

Federal Mediation and Conciliation Service

Federal Mine Safety and Health Review Commission

Federal Open Market Committee**

Federal Reserve System

Federal Retirement Thrift Investment Board

Federal Trade Commission

General Services Administration

Institute of Museum and Library Services

Inter-American Foundation

Legal Services Corporation

Merit Systems Protection Board

Millennium Challenge Corporation

National Aeronautics and Space Administration

National Archives and Records Administration

National Capital Planning Commission

National Credit Union Administration

National Endowment for the Arts

National Endowment for the Humanities

National Indian Gaming Commission

National Labor Relations Board

National Mediation Board

National Science Foundation

National Transportation Safety Board

Nuclear Regulatory Commission

Occupational Safety and Health Review Commission
Office of the Director of National Intelligence

Office of Government Ethics

Office of Navajo and Hopi Indian Relocation

Office of Personnel Management

Office of Special Counsel

Overseas Private Investment Corporation

Peace Corps

Pension Benefit Guaranty Corporation

Postal Regulatory Commission

Railroad Retirement Board

Securities and Exchange Commission

Selective Service System

Small Business Administration

Social Security Administration

Special Inspector General for Iraq Reconstruction

Surface Transportation Board

Tennessee Valley Authority

United States African Development Foundation

United States Copyright Office

United States International Boundary and Water

Commission

United States International Trade Commission

United States Postal Service

United States Trade and Development Agency* 


\section{Appendix B. Form of FOIA Requests Sent to Federal Agencies, May 9, 2010}

\section{[BASELINE]}

To Whom It May Concern:

Under the Freedom of Information Act, 5 U.S.C. \$ 552, I am requesting copies of the following sets of records from the Department of Agriculture:

- $\quad$ The agency's FOIA log from 2010 or equivalent listing the FOIA request number, name of requester, and a description of the records being requested.

If there are any fees for searching or copying the records, please let me know before you fill my request. Or, please supply the records without informing me of the cost if the fees do not exceed $\$ 200$, which I agree to pay. This request is for educational purposes.

If you deny all or any part of this request, please cite each specific exemption you think justifies your withholding of information. Notify me of appeal procedures available under the law.

If you have any questions about handling this request, you may reach me by email at xxxx, or by telephone at xxxx.

Sincerely,

$x x x x$

$x x x x$

$x x x x$

\section{[POLITICALLY SENSITIVE]}

\section{To Whom It May Concern:}

Under the Freedom of Information Act, 5 U.S.C. \$ 552, I am requesting copies of the below-listed sets of records from Department of Agriculture. If there are any fees for searching or copying the records, please let me know before you fill my request. Or, please supply the records without informing me of the cost if the fees do not exceed $\$ 200$, which I agree to pay. This request is for educational purposes.

If you deny all or any part of this request, please cite each specific exemption you think justifies your withholding of information. Notify me of appeal procedures available under the law.

If you have any questions about handling this request, you may telephone me at xxxx. I can also be reached via email at xxxx.

Sincerely,

$x x x x$

$x x x x$

$\operatorname{xxxx}$

Requested Records: A list of the FOIA requests from 2010 about which a political appointee (persons appointed under schedule C, a non-career member of the Senior Executive Service, or Senate-confirmed appointee) personally made an inquiry, personally reviewed, or personally had a hand in the disposition of the request. 
Appendix C. Logit Models of FOIA Responses: Influence of Politicization on Whether Agencies Confirm or Fill Requests

\begin{tabular}{|c|c|c|c|c|c|c|}
\hline & $\begin{array}{l}\text { Confirm } \\
\text { (Coef.) } \\
\text { (S.E.) }\end{array}$ & $\begin{array}{l}\text { Confirm } \\
\text { (Coef.) } \\
\text { (S.E.) } \\
\end{array}$ & $\begin{array}{l}\text { Confirm } \\
\text { (Coef.) } \\
\text { (S.E.) } \\
\end{array}$ & $\begin{array}{l}\text { Respond } \\
\text { (Coef.) } \\
\text { (S.E.) }\end{array}$ & $\begin{array}{l}\text { Respond } \\
\text { (Coef.) } \\
\text { (S.E.) } \\
\end{array}$ & $\begin{array}{l}\text { Respond } \\
\text { (Coef.) } \\
\text { (S.E.) }\end{array}$ \\
\hline \multicolumn{7}{|l|}{ Politicization } \\
\hline $\ln ($ Appointees/Employees)*100 & & $\begin{array}{l}-0.64 * * \\
(0.28)\end{array}$ & $\begin{array}{l}-0.49 \\
(0.38)\end{array}$ & & $\begin{array}{l}-0.50 * * \\
(0.23)\end{array}$ & $\begin{array}{l}-0.36 \\
(0.35)\end{array}$ \\
\hline $\begin{array}{l}\ln (\text { Appointees/Employees }) * 100 * \\
\text { Politically sensitive request }\end{array}$ & & & $\begin{array}{l}-0.26 \\
(0.43)\end{array}$ & & & $\begin{array}{l}-0.24 \\
(0.41)\end{array}$ \\
\hline FOIA office in Secretariat $(0,1)$ & $\begin{array}{l}1.01 \\
(0.76)\end{array}$ & $\begin{array}{l}1.51 \\
(1.06)\end{array}$ & $\begin{array}{l}1.51 \\
(1.06)\end{array}$ & $\begin{array}{l}-0.02 \\
(0.52)\end{array}$ & $\begin{array}{l}-0.09 \\
(0.56)\end{array}$ & $\begin{array}{l}-0.09 \\
(0.56)\end{array}$ \\
\hline \multicolumn{7}{|l|}{ Agency Characteristics } \\
\hline $\operatorname{EOP}(0,1)$ & $\begin{array}{l}-0.16 \\
(0.78)\end{array}$ & $\begin{array}{l}0.72 \\
(0.70)\end{array}$ & $\begin{array}{l}0.74 \\
(0.71)\end{array}$ & $\begin{array}{l}0.26 \\
(0.76)\end{array}$ & $\begin{array}{l}0.90 \\
(0.72)\end{array}$ & $\begin{array}{l}0.94 \\
(0.73)\end{array}$ \\
\hline Cabinet $(0,1)$ & $\begin{array}{l}-0.18 \\
(0.46)\end{array}$ & $\begin{array}{l}-0.19 \\
(0.60)\end{array}$ & $\begin{array}{l}-0.19 \\
(0.60)\end{array}$ & $\begin{array}{l}-0.49 \\
(0.37)\end{array}$ & $\begin{array}{l}-0.16 \\
(0.50)\end{array}$ & $\begin{array}{l}-0.16 \\
(0.49)\end{array}$ \\
\hline Ind. Admin. $(0,1)$ & $\begin{array}{l}-0.02 \\
(0.51)\end{array}$ & $\begin{array}{l}-0.04 \\
(0.54)\end{array}$ & $\begin{array}{l}-0.04 \\
(0.55)\end{array}$ & $\begin{array}{l}0.28 \\
(0.46)\end{array}$ & $\begin{array}{c}0.26 \\
(0.49)\end{array}$ & $\begin{array}{c}0.26 \\
(0.50)\end{array}$ \\
\hline ln(Agency Employment) & & $\begin{array}{l}-0.12 \\
(0.12)\end{array}$ & $\begin{array}{l}-0.12 \\
(0.11)\end{array}$ & & $\begin{array}{l}-0.13 \\
(0.09)\end{array}$ & $\begin{array}{l}-0.13 \\
(0.09)\end{array}$ \\
\hline \multicolumn{7}{|l|}{ FOIA Office Details } \\
\hline $\begin{array}{l}\text { Number of FOIA Requests FY } \\
2010 \text { /\# FOIA Employees FY } 2010\end{array}$ & & $\begin{array}{l}-0.00 \\
(0.00)\end{array}$ & $\begin{array}{l}-0.00 \\
(0.00)\end{array}$ & & $\begin{array}{l}0.00 \\
(0.00)\end{array}$ & $\begin{array}{l}0.00 \\
(0.00)\end{array}$ \\
\hline Politically Sensitive Request $(0,1)$ & $\begin{array}{l}-0.64 * * \\
(0.30)\end{array}$ & $\begin{array}{l}-0.62 * \\
(0.33)\end{array}$ & $\begin{array}{l}-0.37 \\
(0.45)\end{array}$ & $\begin{array}{l}-0.74 * * \\
(0.27)\end{array}$ & $\begin{array}{l}-0.87 * * \\
(0.30)\end{array}$ & $\begin{array}{l}-0.68 * \\
(0.41)\end{array}$ \\
\hline Constant & $\begin{array}{l}1.89 * * \\
(0.38)\end{array}$ & $\begin{array}{l}3.27 * * \\
(1.07)\end{array}$ & $\begin{array}{l}3.13 * * \\
(1.09)\end{array}$ & $\begin{array}{l}1.54 * * \\
(0.31)\end{array}$ & $\begin{array}{l}2.89 * * \\
(0.84)\end{array}$ & $\begin{array}{l}2.77 * * \\
(0.86)\end{array}$ \\
\hline $\mathrm{N}$ & 246 & 224 & 224 & 246 & 224 & 224 \\
\hline LR Test $(5,8 \mathrm{df})$ & 6.22 & 10.70 & 11.37 & $11.61 * *$ & $14.40 *$ & 14.79 \\
\hline
\end{tabular}

Note: **significant at the 0.05 level; *significant at the 0.10 level in two-tailed tests. Robust standard errors, clustered at agency level, reported in parentheses. Base category is an independent commission receiving a baseline request with a FOIA office outside the office of the secretary, administrator, director, or commission chief. 